JOSUÉ RABELO DE ARRUDA

\title{
ESTUDOS EM MODELOS REDUZIDOS DE ESTRUTURAS GEOLÓGICAS POR ELETRORRESISTIVIDADE
}

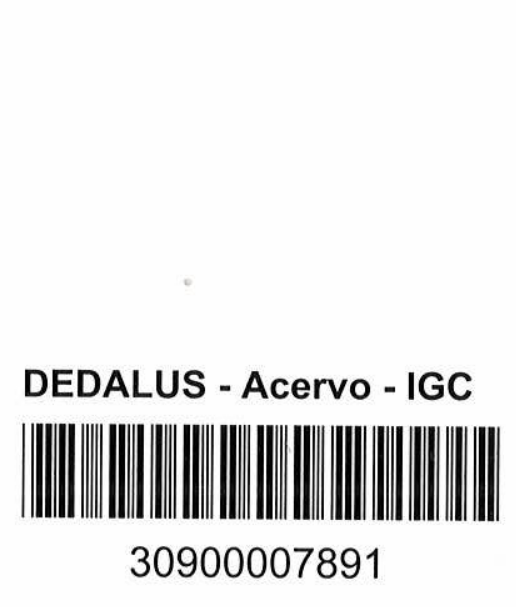

VOLUME I

Dissertação de Mestrado apresentada ao Instituto de Geociências da Universidade de São Paulo

Orientador :

Prof. Dr. André Davino 


\section{INDICE}

\section{VOLUME I}

RESUMO

CAPITULO I

1. INTRODUÇÃO

1.1 - HISTÓRICO DA PESQUISA 1

1.2 - HISTŌRICO DA GEOFISICA APLICADA 2

CAPITULO II

2. ESTUDO DE MODELOS DE ESTRUTURAS GEOLOGICAS EM LABORATORIO POR METODOS GEOFISICOS 7

2.1 - INTRODUÇÃO

2.2 - RESISTIVIDADE

2.2.1 - Campo Elëtrico Gerado por Corrente Contínua

2.2.2 - Definição

2.2 .3 - Tipos de Condutibilidade Elétrica 10

2.3 - FATORES QUE INFLUENCIAM A RESISTIVIDADE DAS ROCHAS

2.3 .1 - Soluções

2.3 .2 - Intemperismo

2.3.3 - Constituintes Mineralögicos

2.3 .4 - Relação Sinal-Ruído

2.4 - INTERPRETAÇÃO GEOFISICA DAS ESTRUTURAS GEOLOGICAS

$2.4 .1-$ Litologia

2.4.2 - Profundidade

2.4 .3 - Forma 
3. DEFINIÇÃO E IMPORTÂNCIA DO MODELO REDUZIDO

3.1 - INTRODUÇÃO

3.2 - MODELOS REDUZIDOS PARA MËTODOS SISMI $\cos$

3.3 - MODELOS REDUZIDOS PARA O MÉTODO MAGNETOMÉTRICO

3.4 - MODELOS REDUZIDOS PARA MËTODOS ELETROMAGNEETICOS

3.5 - MODELOS REDUZIDOS PARA O MÉTODO DA RESIST IVIDADE

4. LABORATORIO DE GEOFISICA APLICADA DE RIO CLARO

4.1 - EQUIPAMENTO DE MEDIDAS

4.2 - MODELOS REDUZIDOS

4.2.1 - Rocha Encaixante

4.2.2 - Rocha Encaixada

4.3 - DISPOSITIVO PARA ELABORAÇÃO DE CARTAS DE ISORRESISTIVIIADE

4.4 - ANÁLISE DOS ERROS QUE AFETAM A MEDIDA DA RESISTIVIDADE

4.4.1 - Equipamentos Eletrônicos

4.4.2 - Cuba Eletrolítica

4.4 .3 - Solução

4.4.4-Eletrodos 
4.4.5 - Cabos Isolados

4.4.6 - Modelos

4.5 - IMPORTÂNCIA DA ESCALA NOS MODELOS REDUZIDOS

5. EXPERIENCIAS DE LABORATORIO

5.1 - VERIFICAÇÃO EXPERIMENTAL DE ALGUMAS CONSIDERAÇðES TEORICAS

5.2 - APLICABILIDADE DA ANÁLISE DE TENDÊN CIA EM MODELOS REDUZIDOS

5.3 - POTENCIAL EXPONTÂNEO

CAPITULO VI

6. CONCLUSOES

CAPITULO VII

7. AGRADECIMENTOS

CAPITULO VIII

8. BIBLIOGRAFIA

VOLUME II

ILUSTRAÇOEES 


\section{RESUMO}

Objetiva este trabalho, relatar a montagem de um labo ratōrio para estudos geofísicos de estruturas geológicas empré gando o parāmetro eletrorresistividade e apresentar alguns resul tados obtidos com a utilização do equipamento no estudo com mode los reduzidos. Procura mostrar algumas dificuldades encontradas durante o trabalho e ressaltar os cuidados a serem tomados para que sejam evitadas diversas fontes de erros nas medidas exper mentais.

Apresenta ainda um apanhado das considerações teōri cas que sustentam alguns dos mētodos usados em Geofísica Aplicá da e, mediante a anālise bibliogrāfica, evidencia comparações feitas entre resultados obtidos com modelos reduzidos e outros resultantes de formulação matemātica, estes atravēs do emprego de computadores. Mostra que em muitos casos, os resultados expe rimentais são mais confiāveis do que os teōricos, mas vezes hā em que os segundos são melhores e outras em que os dois se com plementam. 
CAPITULO I

1. INTRODUÇÃO

\section{l.I - HISTÖRICO DA PESQUISA}

Um dos objetivos visados, quando se resolveu construir - Laboratório de Geofísica Aplicada com modelos reduzidos, em Ribeirão Preto, foi ativar um plano em execução que possibilita ria a existência de um grupo de pesquisadores, no interior deste Estado, com interesse na Geofísica Aplicada.

Para dar prosseguimento à montagem e colocar em funcio namento o referido Laboratōrio, o autor teve a grata satisfação de ser convidado, tendo nessa ocasião iniciado este trabalho.Mas com o inīcio de suas funções didāticas junto ao Instituto de Geociēncias e Ciências Exatas da Universidade Estadual Jūiio de Mesquita Filho - UNESP, campus de Rio Claro, e levando em conta o tempo dispendido em viagens e seu custo material, optou-se pe 1 a montagem de semelhante Laboratōrio em Rio Claro, a partir da experiência inicial de Ribeirão Preto.

Esta decisão baseou-se, primordialmente, no desejo de melhorar as condições didāticas para o ensino da disciplina de Geofísica Aplicada, devido às facilidades com as quais se passa ria a contar para as aulas práticas, principalmente na familia rização com o manuseio dos equipamentos e visualização de impor tantes conceitos teōricos.

Assim, o Laboratōrio de Geofísica Aplicada de Ribeirão Preto não sofreu solução de continuidade, graças a interessante pesquisa desenvolvida por Alfio Bogdan e atualmente o Curso de Geologia existente em Rio Claro conta com importante ferramenta para suas atividades didāticas. 


\section{2 - HISTÓRICO DA GEOFísicA APLICADA}

Convencionalmente, a Geofísica pode ser dividida em duas partes distintas: Pura e Aplicada. A Geofísica Pura estu da a Terra como um todo e os seus objetivos abrangem estudos de problemas sem atentar para seus aspectos económicos imedia tos. A Geofísica Aplicada estuda partes isoladas da crosta te restre com objetivos quase sempre de natureza econômica, em bus ca de bens minerais ou do conhecimento da natureza e condições das rochas de subsuperfĩcie, para orientação dos projetos da Engenharia em obras de mëdio e grande porte.

Esta divisão da Geofísica se fez necessāria apenas nestes $\bar{u} 1$ timos anos pois, no inīcio, eram estudados tão somente fenōmenos naturais objetivando a aquisição de conhecimentos so bre os mesmos.

CARLSBORG (1963) em PARASNIS (1973) sugere a idēia de que a Geofísica Aplicada teve seu nascimento quando do lançamen to do livro "De Magnete" de Willian Gilbert, em 1600, no qual - Autor estabeleceu o conceito de um campo geomagnētico geral, com orientação definida em cada ponto da superfície terrestre. Em seguida, por volta de 1640, atravēs da observação de anoma lias locais na orientação do campo geomagnētico, foi encontra da na Suēcia uma ocorrência de magnetita e, no final desse mes mo sēculo, prospecções magnetométricas foram feitas em maior nümero.

RUST (1938) afirma que a aplicação do mētodo de Resis tividade deveu-se a Fred Brown, que em 1883 procurou encontrar depōsitos minerais atravēs da medida da resistência da terra en tre dois eletrodos. Apesar da simplicidade do método, ele apré senta, segundo RUST (1938), inūmeros defeitos, sendo um deles a contribuição muito grande da resistência do terreno imediata mente próximo ao eletrodo, na resistência total do circuito, in dicando que pequenas variações na resistividade desse materia $\overline{1}$ 
provocam grandes variações nas medidas, exceto quando o material é homogêneo, o que raras vezes ocorre.

SCHLUMBERGER em 1912 e SUNDBERG em 1918 introduziram o método do mapa de potencial que permitiu a representação grāfi ca dos efeitos das anomalias subsuperficiais, mas com sérias des vantagens por não permitir representação numērica nem cālculos.

Em 1916, WENNER introduziu o arranjo de quatro eletro dos, eliminando os inconvenientes dos procedimentos anteriores.

Assim, embora o início da Geofísica Aplicada date do século XVII, o seu maior desenvolvimento se deu no século atual, graças à procura do petrōleo e dos bens minerais para a indūs tria bāsica, ou seja, graças à necessidade de energia e de ele mentos cada vez mais baratos, requisitados pelas indústrias.

No inīcio, bastava um simples reconhecimento geológico para se iniciarem perfurações ou aberturas de galerias, pois as ocorrências minerais apresentavam situações tão favorāveis que eram facilmente encontradas.

Com o tempo, as tēcnicas petrolifferas (reconhecimento geolōgico e sondagens mecānicas) tornaram-se muito caras, alēm de serem demoradas e trabalhosas, necessitando-se portanto de tēcnicas mais rāpidas e baratas para a seleção de āreas mais fa voráveis. Por isso, foram desenvolvidos aparelhos cada vez mais complexos e precisos, como aqueles que se utilizam em mētodos aeroportados, em sĩsmica de reflexão, etc..

Por sua vez, a indústria mineira passou gradativamente a trabalhar com teores cada vez menores, alēm da natural e cres cente dificuldade na prospecção de novas jazidas, pois as mais facilmente encontrāveis ou com altos teores, não mais atendiam à demanda crescente de minērio ou estavam em fase final de lavra.

Assim, os mētodos geofísicos passaram a ter importān cia cada vez maior na seleção de āreas que mereceriam um estudo mais detalhado. 
Mesmo os mëtodos geofísicos tornaram-se, com o tempo, mais onerosos, na medida em que foran sendo utilizadas tēcnicas e equipamentos cada vez mais requintados. Assim, as tēcnicas geofísicas não mais puderam ser empregadas sem discriminação, de vido ao seu alto custo, mas apenas para a seleção de algumas zo nas favorāveis em āreas prē-escolhidas a partir de reconhecimen tos geolögicos, associados ou não a outras tēcnicas geológicas.

Portanto, uma sequéncia de utilização de técnicas, tạn to na prospecção petrolîfera como na mineira em geral, foi sendo estabelecida com base no volume de informações possuidas e dese jadas (DAVINO, 1971):

Prospecção do petróleo

- Geologia de superfície

- Aerofotogeologia

- Aeromagnetometria

- Gravimetria

- Magnetometria terrestre

- Sondagens elētricas e mētodo das correntes telüricas

- Métodos sísmicos

- Sondagens mecānicas

Prospeç̧ão mineira

- Geologia regional e fotogeologia

- Mëtodos geofísicos aerotransportados (magnetomëtrico, radiomētrico e eletromagnētico)

- Geologia de detalhe

- Prospecção geoquímica

- Magnetometria terrestre

- Gravimetria

- Métodos elētricos e eletromagnēticos

- Mëtodos sísmicos e outros

- Galerias, sondagens mecânicas, etc. 
Como as prospecções geofísicas tornaram-se cada vez mais caras, as informações procuradas com esses mëtodos tambēm deveriam ser mais precisas, completas e räpidas, de modo a se ob ter uma compensação.

As informações qualitativas obtidas hä trinta ou qua renta anos aträs perderam sua importäncia para as quantitativas, donde novas tëcnicas e equipamentos terem sido desenvolvidos.Mas com o refinamento das tēcnicas, novos problemas foram sendo en contrados e às resoluções matemāticas foi atribuĩda uma pequená importância, visto que sua utilização somente era possĩvel em problemas teöricos simples, dado o grande nümero de variāveis en: contradas:

- todo corpo deve apresentar um tamanho minnimo de acor do com a profundidade em que se encontra, visto que, se possuir dimensões pequenas e profundidade grande, não serä encontrado por mëtodos geofīsicos. Portanto,hä uma relação constante e mí nima entre dimensões e profundidade, abaixo da qual um corpo não serā encontrado;

- o contraste entre as propriedades físicas investiga das, do corpo e da rocha encaixante, deve ser tal que seja pos sỉvel uma distinção clara pelo equipamento utilizado. Por exem plo: dificilmente distinguir-se-ã uma marga argilosa de uma arg $\underline{i}$ 1 a por métodos elētricos, visto suas resistividades apresentarem campos de variação que se superpõem quase totalmente;

- o contraste entre as propriedades físicas deverä ser tanto maior quanto maior for a profundidade das rochas pesquisa das;

- a forma da curva obtida em uma prospecção geofísica e influenciada pela forma, pelo contraste de propriedades, pro fundidade e dimensões do corpo, etc..

Com apenas este pequeno nümero de variäveis pode-se no tar que uma resolução matemätica seria praticamente impossível e restrita a situações simples. 
Por esse motivo, foram desenvolvidas as tēcnicas dos modelos reduzidos para o estabelecimento de curvas-padrão de vá rias situações geolōgicas ideais, para que a anāiise dos dados de campo possibilitasse a resolução do problema inicial (profun didade, dimensões e natureza do objeto). Esta tēcnica foi de senvolvida principalmente para os métodos elētricos, visto se rem estes os mais utilizados e tambēn pela simplicidade de repre sentação em laboratōrio. Modelos reduzidos foram idealizados tam bēm em sīsmica, eletromagnetometria e magnetometria. 


\section{CAPITULO II}

2. ESTUdO DE MODELOS DE ESTRUTURAS GEOLOGICAS EM LABORATORIO POR METODOS GEOFISICOS

\section{1 - INTRODUÇÃO}

As tēcnicas geofísicas envolvem a medida de certos pa râmetros físicos das rochas e minerais, diferindo entre si segun do o parāmetro físico considerado. Interessam apenas aqueles parâmetros que possam provocar ações à distāncia e de significa do compreensīvel, isto é, susceptīveis de explicação atravēs de uma teoria interpretativa. Variações nesses parâmetros provocam distorções na distribuição de certos campos de força. Estas dis torções nos campos de forças são chamadas anomalias e são elas, mais do que os valores absolutos dos campos, de interesse ao ge físico.

Diversos são os parâmetros físicos pesquisados pela Prospecção Geofísica. Dentre eles, destacam-se a densidade, sus ceptibilidade magnētica, cargabilidade (capacidade de polarizá ção), velocidade de propagação das ondas elāsticas e eletrorré sistividade. Os estudos geofísicos procuram determinar a variạ ção dessas propriedades visando conhecer a forma, a profundidade em que se encontra e constituição mineralógica do corpo que pro voca tal variação.

A eletrorresistividade ou mais simplificadamente, re sistividade, muito embora seja uma das propriedades físicas da matēria que mais apresente variação, desperta interesse pela Geofísica Aplicada e serā esta a propriedade em estudo nesta monografia, empregando o Método de Eletrorresistividade. 


\section{$2.2-\quad$ RESISTIVIDADE}

2.2.1 - Campo Elétrico Gerado por Corrente Contínua

Quando a energia elétrica é aplicada em dois pontos da superfície de um terreno, a corrente elētrica flui entre eles de vido à diferença de potencial estabelecida. Se o meio entre os dois eletrodos for homogêneo, a distribuição de corrente e do po tencial será regular e poderá ser calculada.

Considerando dois eletrodos A e B, situados na superfí cie de um terreno homogēneo, entre os quais é estabelecida uma diferença de potencial e um campo elētrico quaisquer, a Figura 1 , representando esta situação, mostra a distribuição do potencial e corrente medidos, entre os dois eletrodos, na superfície do terreno, e em planos vertical e horizontal.

A variação da diferença de potencial e intensidade do campo elëtrico medidas entre dois eletrodos situados na superfí cie de um terreno homogêneo apresenta elevado gradiente nas pro ximidades dos eletrodos, mas tende a zero se for considerado o terço central da distância que separa os mesmos (Figura la).

A distribuição do fluxo de corrente em um plano vertị cal contido em um terreno homogêneo é definida por linhas cônca vas devido à repulsão gerada pelos eletrodos (HEILAND, 1968), com a intensidade de corrente aumentando com a profundidade, enquan to que as linhas equipotenciais são semi-cīrculos somente nas proximidades dos eletrodos (Figura 1b). A Figura lc mostra a mesma distribuição em um plano horizontal contendo a superfície do terreno. 
$2.2 .2-$ Definição

Resistividade $(\rho)$ ou condutibilidade elētrica $(\sigma) \vec{e}$ um parāmetro que relaciona a intensidade de campo (E) e a densidade de corrente $(j)$ a que estā submetido um material (HEILAND, 1968):

$$
\rho=\frac{\vec{E}}{\vec{j}}
$$

Se considerarmos um condutor cilindrico com comprimen to 1 entre dois pontos a e b e ärea de secção reta $S$, podemos es crever que:

$$
i=\int j d S \text { e } V_{a b}=-\int_{a}^{b} E d l
$$

Se o condutor apresentar secção reta constante, sua re sistência será:

$$
\begin{aligned}
R & =\frac{V a b}{i}=\frac{-\int_{a}^{b} E d I}{\rho j d S} \\
R & =\frac{E \cdot 1}{j \cdot S} \text { ou } R=\rho \frac{1}{S} \\
\text { concluindo-se que } \rho & =\frac{\Delta V}{i} \cdot \frac{S}{1}
\end{aligned}
$$

A equação I mostra-nos que a unidade da resistividade $\vec{e}$ a unidade de resistência (ohm), multiplicada pela unidade de comprimento (metro). Em Geofísica Aplicada, alēm do metro, cos tuma-se usar tambëm o centimetro, originando assim uma unidade cem vezes menor. Assim, a resistividade pode ser entendida como sendo a medida da dificuldade que a corrente elëtrica encontra ao atravessar um determinado material (ORELLANA, 1972). 
Nos trabalhos geofísicos, excetuando algumas situações geolögicas nas quais o material investigado apresenta extensas dimensões horizontal e vertical, alēm de boa homogeneidade elé trica, não é medida a resistividade verdadeira, mas um valor que reflete a influência no campo elétrico estabelecido, não apenas do objeto em estudo, mas tambēm, em maior ou menor intensidade, de outros corpos vizinhos. 0 valor encontrado nestas circunstân cias $\bar{e}$ denominado resistividade aparente.

Se for considerado um terreno composto de infinitos ma teriais com caracterīsticas elētricas diferentes, a resistivida de aparente medida na sua superfīcie atravēs de um determinado ar ranjo de eletrodos é definida como sendo aquela resistividade ob tida em um terreno homogêneo, ünico e fictício, empregando o mes mo arranjo de eletrodos. Portanto, a resistividade aparente de pende da repartição da resistividade em subsuperfície e do arran jo de eletrodos empregado.

\subsection{3 - Tipos de Condutibilidade Elëtrica}

Nos minerais, a condutibilidade elētrica pode ocorrer por meio de processos eletrōnicos ou iônicos, admitindo-se no primeiro caso a condutibilidade metālica e a de semicondutores e no segundo, aquela que ocorre em eletrólitos sōlidos e líquidos.

\section{Condutibilidade Metälica}

$\mathrm{Na}$ natureza, poucos são os minerais que apresentam con dutibilidade metālica (elementos nativos). Os mais comuns são - cobre e o ouro, embora muito raramente sejam encontrados ou tros como platina, irídio, ósmio e ferro. Os minerais de outras classes que apresentam este tipo de condutibilidade são mais ra ros ainda, como, por exemplo, a ulmanita (NiSbS); a grafita è um 
caso à parte por apresentar dois valores, conforme seja medida em direção paralela ou perpendicular à sua clivagem.

A condutibilidade metälica pode ser entendida como de vida à presença de elētrons de valência que necessitam de ener gia muito pequena para serem deslocados, podendo ser considera dos como sem vínculo a qualquer ätomo. A existência de aproxima damente $1.10^{22}$ elētrons de valëncia por centimetro cūbico confe re a estes materiais uma infima resistência elëtrica, a qual, pó rēm, $\bar{e}$ afetada pela temperatura, presença de impurezas e defei tos ou deslocamentos na rede cristalina.

A temperatura provoca uma diminuição na condutibilida de eletrônica devido ao aumento da vibração atōmica,dificultando assim a movimentação dos elētrons. A presença de impurezas e de feitos ou deslocamentos na rede cristalina tambēm tende a difi cultar a movimentação dessas partĩculas, acarretando diminuição da mobilidade dos elétrons livres. Assim, condutores eletrōn cos homogẽneos deverão, pelo menos teoricamente, apresentar re sistência nula se possuirem redes cristalinas perfeitas e estive rem a zero graus absoluto.

A Tabela 1 (KELLER \& FRISCHKNECHT, 1966) relaciona a resistividade de alguns metais refinados e minerais que apresen tam condutibilidade metälica, medida com corrente contínua.

\section{Semicondutores}

Semicondutores são materiais nos quais a condução, por movimentação eletrōnica, ē em escala menor que nos metais verda deiros. A menor condutibilidade elëtrica não se deve à menor mo bilidade dos elëtrons, mas à menor quantidade dos mesmos em rela ção aos metais.

Estes diferem dos metais por necessitarem de uma quan tidade de energia muito maior para liberar o movimento dos elë trons. Esta energia suplementar, se oriunda de uma fonte de ca 
TABELA I

RESISTIVIDADE DE METAIS E MINERAIS METALICOS (corrente continua) METAIS REFINADOS A $0^{\circ} \mathrm{C}$ (resistividade $\times 10^{-8}$ ohm.m)

\begin{tabular}{|c|c|c|c|}
\hline Aluminto & 2,5 & Lantānio & 59 \\
\hline Antimōnio & 36 & Litio & 8,5 \\
\hline Arsēnio & 35 & Magnēsio & 4,0 \\
\hline Bärio & 59 & Molibdēnio & 4,3 \\
\hline Berílio & 5,5 & Niquel & 6,3 \\
\hline Bismuto & 100 & Osmio & 9,1 \\
\hline cādmio & 6,7 & ouro & 2,0 \\
\hline cálcio & 4,2 & Palādio & 10,0 \\
\hline cērio & 71 & Platina & 9,8 \\
\hline Césio & 18 & Potāssio & 6,3 \\
\hline Chumbo & 19 & Praseodímio & 62 \\
\hline Cobalto & 6,3 & Prata & 1,5 \\
\hline Cobre & 1,6 & Rênio & 4,5 \\
\hline Crōmio & 15,3 & Rubidio & 11,6 \\
\hline Estanho & 10,0 & Rutēnio & 11,7 \\
\hline Estrōncio & 33 & Södio & 4,3 \\
\hline & & Tāntalo & 14 \\
\hline Ferro & 9,0 & Telürio & 14 \\
\hline Gālio & 41 & Titānio & 83 \\
\hline Hāfnio & 29 & Tungstênio & 5,0 \\
\hline Indio & 8,5 & Zinco & 5,5 \\
\hline Irĩdio & 5,0 & Zircōnio & 42 \\
\hline
\end{tabular}

\footnotetext{
MINERAIS METALICOS

Breithauptita 3,0 a $50 \times 10^{-8}$

Cobre nativo 1,2 a $30 \times 10^{-8}$

Grafita

36 a $100 \times 10^{-8}$ (fluxo de corrente

28 a $9.900 \times 10^{-6}$ (fluxo de corrente per

Ulmanita(NiSbS) 9,0 a $120 \times 10^{-8}$ pendicular à clivagem)
} 
lor, permite que seja estabelecida uma proporcionalidade entre o nümero de elētrons livres e a temperatura a que estā submetido o semicondutor, de tal forma que a relação è direta.

A relação direta entre a condutibilidade dos semicondu tores e a temperatura permite que seja estabelecida outra discré pância entre estes e os metais, visto ser inversa a relação en tre quantidade de elétrons livres e a temperatura nestes ūitimos.

Todos os materiais que não apresentam condutibilidade eletrōnica elevada são semicondutores, em maior ou menor grau. Se um material exige uma baixa energia de ativação, poderā ser considerado tão condutor como um metal, sendo este o caso de muitos sulfetos metālicos. Mas se for elevada a energia de at $\underline{i}$ vação, poderā ser considerado um perfeito isolante. Baixas coñ dutibilidades eletrōnicas são encontradas em muitos minerais sí licāticos e, sob circunstāncias normais, a condução eletrōnicá pode ser considerada desprezīvel em comparação à condução iônica.

os minerais metāilicos possuidores deste tipo de condu ção elētrica apresentam valores de resistividade muito variāveis. Esta variação deve-se não apenas a imperfeições existentes nos cristais ou impurezas que podem tornä-los mais ou menos resis tentes, mas tambēm à sua forma de cristalização.

ORELLANA (1972) analisando vārios trabalhos que rela cionam resistividades de minerais metālicos encontrou discre pâncias em valores atribuídos a um mesmo mineral e concluiu que este fato se deve à grande variação apresentada pelos mesmos. Esse Autor cita o exemplo da pirita que, embora seja um mineral com baixa resistividade, pode apresentar-se com variação de atē cinco ordens decimais.

Mas considerando a composição quỉmica desses minerais, geralmente os sulfetos, arsenietos e teluretos apresentam valo res muito pequenos para resistividade, enquanto os ōxidos e com postos de antimônio tendem a comportar-se como maus condutores. 
Eletrölitos Sólidos

Eletrōlitos sōlidos são substâncias nas quais a condu ção de uma corrente elētrica dā-se pela movimentação de Tons den tro do reticulo cristalino.

Nestas substāncias os elētrons estão presos por forças tão elevadas que a energia necessāria para.permitir condutibili dade eletrōnica seria muito prōxima daquela requerida para provo car fusão do material.

ORELLANA (1972) relaciona alguns minerais que apresen tam este tipo de condutibilidade elëtrica. Dentre eles desta cam-se os mais comuns na crosta terrestre: calcita, quartzo, feldspatos, feldspatöides, hornblenda, limonita, micas, 01 ivinas, e piroxēnios. Nesta relação de minerais e grupos mineralögicos são encontrados os minerais que originam a grande maioria de ro chas da crosta terrestre, sendo devido a este fato os altos valo res de resistividade encontrados em rochas secas.

os minerais formadores de rochas geralmente são com plexos agrupamentos de silicatos de aluminio e cätions metāicos, estes substituindo-se mutuamente. Devido à diferença de tamanho entre o silicato de aluminio e os cātions, estes ūltimos podem movimentar-se de uma posição a outra, dentro da rede cristalina, originando irregularidades chamadas de defeitos de schottky. Por outro lado, a vibração tērmica pode provocar a movimentação de um ion de uma posição a outra, originando os defeitos de Frenkel. Estes movimentos ionicos ao acaso podem ser orientados por um campo elëtrico, originando assim uma fraca corrente elëtrica. Es tes materiais possuem resistividade geralmente superior a $10^{7}$ ohm.m.

Eletrólitos Líquidos

Eletrōlitos lĩquidos são formados pela dissolução de 
um sal em um solvente, originando-se, portanto, uma solução. Nes ta, os sais encontram-se dissociados, podendo os seus ions movi mentarem-se. Ao ser aplicado um campo elëtrico essa movimenta ção orientar-se-ă com o campo aplicado, originando uma corrente elētrica.

A movimentação iōnica depende da intensidade do campo elētrico aplicado, temperatura, concentração e tamanho do ĩon. A relação entre a movimentação iōnica e a intensidade do campo elētrico aplicado ē direta, o mesmo acontecendo com a temperatü ra, pois o aumento desta acarreta diminuição da viscosidade do iqquido permitindo, assim, maior facilidade ao deslocamento dos ions.

A concentração e mobilidade iōnicas relacionam-se in versamente, visto que o aumento do nümero de ions presentes na solução acarretará uma interação maior entre os mesmos, provocan do assim uma diminuição de suas respectivas liberdades de movi mentação.

Se for considerado um cubo com um metro de lado ( um metro cübico), com uma diferença de potencial unitäria entre duas faces opostas, a resistividade apresentada por uma solução em seu interior serā:

$$
\rho=\frac{1}{F \sum \alpha_{i} c_{i} m_{i}}
$$

onde

$F=96487$ Coulombs, que corresponde $\bar{a}$ carga de cada equivalente grama,

$\alpha=$ fator de dissociação, pois nem todas molēculas estão disso ciadas,

$c=$ concentração do sal.

$m=$ mobilidade do Ton considerado, ã temperatura do experimento. 
Esta equação permite o conhecimento da resistividade de uma solução, desde que sejam conhecidos os diferentes fons.

A equação II mostra que hā uma relação inversa entre a mobilidade iónica e a resistividade de uma solução. Assim, có mo a temperatura aumenta a mobilidade iônica, pela equação II con clui-se que provocarä uma diminuição da resistividade.

A diminuição da resistividade com o aumento da tempe ratura è indicada pela equação III:

$$
\rho_{T}=\frac{\rho_{0}}{1+a\left(T-T_{0}\right)}
$$

onde $\rho_{T} \vec{e}$ a resistividade da solução à temperatura $T$; $\rho_{0}$ é a resistividade à temperatura de referēncia, sendo gera 1 mente igual a $18^{\circ} \mathrm{C}$; e a è um coeficiente aproximadamente igual a 0,022 . Esta equação, embora não forneça dados exatos, è vāi da dentro das temperaturas normais (ORELLANA, 1972).

Embora a equação II possa ser aplicada no estudo da resistividade de āguas naturais, visto serem consideradas solu ções, sua aplicabilidade é dificultada pela grande quantidade de diferentes sais dissolvidos.

Os Tons mais comuns nas äguas naturais são o $\mathrm{Na}^{+} \mathrm{e} 0$ C1: Este fato permite a determinação da quantidade total de sais dissolvidos em soluções diferentes, atravës do conceito de equi valente de salinidade.

KELLER \& FRISCHKNECHT (1966) definem equivalente de salinidade de uma solução como sendo a quantidade de cloreto de sōdio dissolvido, necessāria para ser obtida resistividade iden tica à da solução em particular. Este conceito é muito ütil por dispensar anälises químicas ao se desejar, por exemplo, estudar a resistividade de soluções, podendo ser aplicado a soluções di ferentes desde que a mobilidade dos íons não varie muito.

A Figura 2 mostra a variação da resistividade de uma 
solução de cloreto de sōdio com a temperatura e a concentração do sal, e foi adaptada daquela publicada pela SCHLUMBERGER WELL SURVEYING CORPORATION (1960).

\section{3 - FATORES QUE INFLUENCIAM A RESISTIVIDADE DAS ROCHAS}

A maioria das rochas que compõe a crosta terrestre é formada por minerais que apresentam condutibilidades eletrōnicas e iônicas muito pequenas, sendo, portanto, consideradas como ma teriais isolantes. Mas suas propriedades elētricas geralmente são alteradas pela presença de soluções em seus poros, pelo in temperismo e tambēm pelos constituintes mineralōgicos.

\section{3 .1 - Soluções}

Soluções estão presentes na maioria das rochas devido à presença de poros e ligações entre eles, favorecendo a condu ção de corrente elétrica. Essa condutibilidade eletrolítica dé pende da porosidade e permeabilidade do material da quantidá de de àgua presente e sais dissolvidos.

Os poros são divididos, por KELLER \& FRICHKNECHT(1966), em poros de armazenagem e de conexão. Os poros de conexão desem penham função mais importante na variação da resistividade da ro cha que os primeiros, por serem eles os responsāveis pela distrí buição da corrente elētrica na rocha. Exemplo deste fenōmeno ē encontrado em rochas vulcānicas, visto predominarem os poros de armazenamento.

A relação teōrica entre a porosidade e a resistivida de de rochas tem sido estudada atravës de formulação matemātica. Mas devido à variação da geometria desses vazios, tal estudo so 
mente $\vec{e}$ possīvel, na prätica, por meio de considerações empīr cas.

Importante relação experimental entre a resistividade e a porosidade $\overline{\mathrm{e}}$ dada pela lei de Archie:

$$
\rho_{r}=p^{-m} \rho_{a}
$$

onde $\rho_{r} \overrightarrow{\mathrm{e}}$ a resistividade da rocha, $\rho_{a} \overrightarrow{\mathrm{e}}$ a resistivi dade da āgua presente em seu interior, $P \bar{e}$ a porosidade e $m \overline{\bar{e}}$ chamado de coeficiente de cimentação.

Esta mesma equação, apresentando um coeficiente a que parece depender da textura da rocha e varia geralmente entre 0,5 e 2,5 , è chamada equação de Winsauer:

$$
\rho_{r}=a p^{-m} \rho_{a}
$$

0 expoente m pode variar de 1,3 para rochas detrit cas fracamente cimentadas atē 2,3 para calcärios e dolomitos de granulação muito fina.

A equação $V$ pode ser relacionada a outra caracterīs tica das rochas, chamada fator de formação, constante para cada rocha e relacionado com sua porosidade, através da equação:

$$
F=\frac{\rho_{r}}{\rho_{a}}
$$

que substituído na equação $V$, estabelece uma relação com a poro sidade

$$
F=a p^{-m}
$$

A equação VII é importante por permitir a determina ção da porosidade de uma rocha sem a necessidade da execução dos ensaios de porosidade, pois o conhecimento das resistividades da rocha e da āgua contida é obtido mais facilmente. Embora a de 
terminação do fator de formação seja simples, o valor obtido não e perfeitamente correto, pois ao ser retirada a āgua da rocha, permanecerá certa quantidade de sal fazendo com que a resistivi dade da solução seja diferente da real.

A Figura 3 mostra a relaçäo entre o fator de formação e a porosidade de rochas com diferentes valores de a e $\underline{m}$. Na impossibilidade da determinação experimental destes coeficientes, KELLER \& FRISCHKNECHT (1966) sugerem a adoção de valores unitä rio para a e dois para $\underline{m}$, por não produzirem graves erros quando a porosidade estā compreendida entre $10 \%$ e $30 \%$, que são as mais comuns em rochas sedimentares.

As equações IV, V, VI e VII são välidas para rochas saturadas de ägua e sem partĩculas argilosas. Rochas não satura das permitem o aparecimento da condução superficial e naquelas com particulas argilosas ocorre o fenómeno chamado ionização dos minerais de argila.

A condução superficial tem como origem a existência de cargas elētricas na superfície dos poros. Essas cargas, de correntes da pröpria estrutura cristalina, aparecem quando as partĩculas minerais apresentam diāmetros inferiores ao da argila. Nos minerais silicäticos as cargas são negativas devido à presen ça dos ätomos de oxigênio na superfície do mineral, as quais pro vocam a orientação das molëculas de ägua que recobrem a superfĩ cie interna dos poros. Assim, rochas insaturadas em ägua tem os poros revestidos de uma fina camada de molēculas de ägua orienta das, as quais conferem a esse líquido uma resistividade menor do que a do estado natural, onde não hä orientação molecular. Estão adsorvidos tambëm ĩons, que juntamente com a āgua originam uma camada condutora com atē vārias molēculas de espessura. E è essa camada que provoca erros nas determinações da porosidade atravēs do fator de formação. Mas se a rocha estiver completamente satu rada, este fenómeno provocarā uma variação desprezĩvel na condu tibilidade total.

Minerais apresentando granulação de argila possuem a 
capacidade de adsorver cätions que podem ser trocados por ou tros existentes na ägua. Essa troca iōnica ē mais predominante em minerais de argila dos grupos da Montmorilonita, Vermiculita e Haloisita, entre outros. Como esses ions não tem jgual tama nho, forma-se uma camada difusa de cătions, possuindo certa $1 \underline{j}$ berdade de movimentação aqueles que estiverem mais distantes da partīcula de argila. A àgua retirada de semelhante rocha tambēm apresentarā resistividade maior, devido à retenção da maioria dos cātions junto à partícula argilosa.

0 fenômeno de ionização dos minerais de argila apre senta pequena influēncia quando a solução possui elevada salini dade, visto que a retenção de sais pouco alterará a condutibili dade da ägua examinada fora da amostra; mas nas rochas que pos suem baixa salinidade notar-se-ão os efeitos deste fenômeno.

\section{3 .2 - Intemperismo}

0 intemperismo contribui muito para o decrēscimo da resistividade das rochas, principalmente igneas e metamōrficas, visto serem as rochas sedimentares menos sensiveis a estes pro cessos, tendo-se em mente o parāmetro resistividade. Essa esta bilidade não pode ser estendida às rochas carbonäticas pelo fato de sua permeabilidade aumentar com a dissolução, fenómeno que provoca decrēscimo em sua resistividade.

A atuação dos agentes intempēricos nas rochas crista linas, provocando aumento da sua condutibilidade elétrica, deve-se ao fato de seus minerais serem transformados em argilo-mine rais, os quais apresentam maior capacidade de transmissão de cor rente elétrica, como foi analisado anteriormente.

A transformação destes minerais originais em argilo- minerais ocorre atravēs de reações quïmicas que provocam a dimi nuição da resistividade da solução, visto nessas reações ocorre 
rem liberação de cātions e ānions. Essa alteração da condutibi lidade elētrica da solução ē tão intensa que àguas cognatas, pre sentes em rochas cristalinas, apresentam resistividades variando entre 0,03 e 10 ohm.m. (ORELLANA, 1972).

0 fraturamento desempenha importante função não ape nas por facilitar a ação dos agentes intempëricos, como tambēm por aumentar a porosidade da rocha. Este aumento da porosidade favorece a percolação da āgua, o que diminui consideravelmente a resistividade da rocha.

\subsection{3 - Constituintes Mineralógicos}

As rochas podem conter minerais que diminuem conside ravelmente sua resistividade. Muito embora sejam numerosos aqueles minerais que poderiam influenciar a condutibilidade ele trica, somente a magnetita, hematita especular, grafita, pirita e pirrotita o fazem, devido à maior abundāncia em relação aos outros (KELLER \& FRICHKNECHT, 1966).

Este fenōmeno ë encontrado apenas em poucas localida des. Para que tal fato ocorra, desempenha importante papel o häbito mineralögico. A Figura 4 mostra a variação da resistivi dade de um gabro da região central de Maine (U.S.A.) com o con teüdo em peso de pirrotita e pentlandita dendríticas. Nota-se que ate aproximadamente $3 \%$ em peso destes minerais não hä altera ção na resistividade das rochas, mas a partir deste valor o com portamento elētrico do material é tão alterado que aproximadamen te $11 \%$ em peso é suficiente para diminuir a resistividade ini cial a 10 ohm.m.

MURASHOV, citado por ORELLANA (1972), estudou ocor rências com mais de $70 \%$ de calcopirita, talvez com häbito granu 1 ar, sem que a resistividade fosse alterada. Conclui-se, portan to, que o häbito mineralögico desempenha importante função, pois 
hăbitos dendriticos contribuem para um decréscimo de resistivida de muito maior que o granular.

2.3 .4 - Relação Sinal-Ruído

SUMNER (1976) define ruĩdo elëtrico como sendo qual quer diferença de potencial indesejāvel às medidas executadas, e ruído geolögico àquele provocado pela interferência de condições geológicas estranhas ao objetivo. Sinal é definido, pelo mesmo Autor, como aquela diferença de potencial que traz informações sobre o objetivo em estudo.

As tëcnicas e equipamentos empregados em estudos geo físicos visam sempre estabelecer uma adequada relação entre sí nal e ruỉdo. Relações sinal-ruĩdo unitärias são indesejāveis, pois ambos confundem-se na maioria dos métodos. Portanto, os procedimentos de campo, como os de construção dos equipamentos, visam sempre o uso da maior relação possivel, atribuindo-se uma confiabilidade maior aos dados coletados.

0 ruído, quer seja decorrente de condições internas ou externas aos equipamentos empregados, não interfere na pro priedade em estudo, mas na sua determinação. Assim, a medida de uma propriedade física pode apresentar um erro devido a esta interferência.

Sua origem é variada, podendo ser causada pela ativi dade humana, condições naturais ou por uma deficiência do prō prio equipamento empregado.

Diversas são as soluções adotadas para serem elimina dos os ruidos nas medidas de diferença de potencial. A mais em pregada é a do compensador, na qual opõe-se uma diferença de pó tencial de mesma intensidade àquela recebida pelo equipamento. Este procedimento è muito empregado para ruídos constantes e con tinuos. Procedimento simplista muito usado nestes tipos de rui 
dos è o aumento do sinal enviado pela fonte, muito embora a po tência da fonte não possibilite, às vezes, o seu emprego.

Se a diferença de potencial indesejāvel não for cons tante, poderão ser necessārias outras soluções, como vārias medi das, ou atē aquelas onerosas como o emprego de registradores gra ficos. Mas se proveniente de uma corrente alternada, o emprego de filtros è recomendado quando a frequência indesejāvel è dife rente daquela empregada pelo equipamento.

Ruî́do geolōgico tambēm è frequente nas medidas elétrí cas realizadas na superficie do terreno. Heterogeneidades co muns são as crostas laterïticas. A eliminação dessas influēn cias, tanto nas tēcnicas de sondagem como nas de caminhamentos elētricos é feita movimentando-se alternadamente os eletrodos de corrente e de potencial. Influências superficiais comuns são aquelas decorrentes da presença de materiais isolantes ou muito condutores aflorantes ou em profundidade. Estes materiais impe dem a obtenção de sinais relativos às rochas situadas abaixo, em bora equipamentos mais potentes às vezes possibilitem a obtenção do sinal desejado.

Equipamentos tambēm provocam ruĩdos, tanto em decor rência de funcionamento defeituoso como tēcnica de operação ina dequada. Um erro comum apresentado por equipamentos è a polari zação dos eletrodos. Este fenōmeno tem sua origem na heteroge neidade das condições químicas dos materiais superficiais, pois, ao serem adicionados eletrodos de potencial, metāicos, cons troi-se uma pilha eletrolítica natural. A eliminação deste ruĩ do é obtida empregando-se eletrodos não polarizāveis. Ruídos pro venientes de mau funcionamento dos componentes eletrōnicos são eliminados, geralmente, apenas atravēs da substituição dos mes mos.

Mas em determinadas circunstāncias não hă possibilida de de ser diminüido ou eliminado o ruido. Nestas situações, de ve ser escolhido um mëtodo ou técnica de campo que permita ele 
var o sinal captado. Assim, a escolha de um arranjo de eletro dos mais adequado ou o emprego de equipamentos mais sensiveis co mo um registrador gräfico pode ser ūtil na determinação do si nal procurado.

Condições topogräficas desfavoräveis tambēm contrị buem para que haja uma diminuição do sinal recebido, como, por exemp 10, uma topografia acidentada, na qual a interferencia cau sada pela percolação da āgua ou outras fontes de ruídos podem ser maiores que o sinal recebido, visto que a deformação do cam po elētrico provocada pela superfície inclinada tenderā a dim nuir muito o sinal.

Portanto, as condições de detectabilidade de um corpo não somente dependem de suas caracteristicas e do mētodo emprega do, mas tambēm do instrumento e tēcnicas de operação, assim como das condições topogräficas e geolögicas (ORELLANA, 1974).

\section{4 - INTERPRETAÇÃO GEOFISICA DAS ESTRUTURAS GEOLOGGICAS}

Todas as tēcnicas empregadas na prospecção de um bem mineral ou mesmo em Geologia Aplicada visam, principalmente, res ponder três questões importantes: 1itologia do corpo rochoso,pro fundidade em que se encontra e sua forma.

0 mëtodo de resistividade emprega, para tanto, duas técnicas, conforme a variação da condutibilidade dos materiais seja vertical ou horizontal.

A sondagem elëtrica $\vec{e}$ um procedimento com o qual pro cura-se investigar a variação da resistividade na vertical de um ponto, enquanto o caminhamento elëtrico preocupa-se com a varia ção horizontal. 
$2.4 .1-$ Li tologia

0 método de resistividade empregado na determinação litolögica é um pouco falho, pois esta propriedade talvez seja a que mais varia. A Figura 5 (ORELLANA,1972) mostra a variação mais comum de algumas rochas e minerais. Desta figura conclui- se que o emprego exclusivo desta propriedade física conduz o intērprete a värias conclusões, mais indefinidas, ainda, se o material apresentar-se fraturado, o que intensifica a ação in tempērica e com isso, amplia-se o campo de variação e de super posição de värios materiais no gráfico.

Mas, esta incerteza pode ser diminuĩda e atē elimina da, se for conhecida a litologia predominante da ārea e tambēm a variação da resistividade de alguns tipos litolögicos.

0 conhecimento litológico regional pode ser obtido empregando as variadas técnicas utilizadas em mapeamentos geo lögicos. Quanto à determinação da resistividade de alguns ou värios tipos litológicos, pode ser executado "in situ" ou em laboratōrio.

Assim, em ordem decrescente de confiabilidade pode riam ser utilizadas as determinações superficiais, seguidas das determinações em poços e finalmente os dados obtidos em 1 abora tōrio, com amostras.

A determinação da resistividade em superfĩcie $\bar{e} a$ que apresenta maior confiabilidade por envolver considerävel vo lume do material e tambëm pelo fato da medição envolvê-lo ém suas condições naturais. Muito embora sejam poucas as situa ções em que podemos fazer uma determinação sem a influência de materiais estranhos ao corpo, como por exemplo, a influência de rochas adjacentes ou heterogeneidades superficiais, sonda gens elētricas permitem a obtenção de bons resultados, embora possa ocorrer alguma ambigluidade relativa à interpretação. Cui 
dados especiais devem ser tomados tambēm, pois as condições geo elētricas da rocha aftorante podem ser diferentes daquelas encon tradas em profundidade, na mesma rocha.

0 conhecimento da resistividade de uma rocha através de uma perfilagem elētrica, embora possa não apresentar o incon veniente da influência de outras rochas, apresenta aquele devido ao pequeno volume de material estudado e principalmente ao custo proibitivo da perfuração e da perfilagem elëtrica, alēm dos er ros introduzidos pela lama de perfuração, se não forem compensa dos.

A determinação da resistividade em amostras no labora törio, embora seja talvez o mētodo mais preciso devido ao fato de poderem ser empregados equipamentos que dificilmente seriam levados ao campo, apresenta inümeros inconvenientes. 0 primeiro deles seria a representatividade da amostra, pois esta além de não representar as condições naturais (parte da água pode ter-se evaporado, aumentando a salinidade e consequentemente diminuindo a resistividade da amostra) poderă tambēm não representar o grau de intemperismo, composição e associação mineralōgica, fatos es tes por si só suficientes para invalidar qualquer determinação. Apesar disso, este mëtodo proporciona resultados interessantes e $\vec{e}$ insubstituivel no estudo de fatores que podem afetar a resisti vidade das rochas, como, por exemplo, o grau de umidade, tempera tura, concentração salina, distribuição mineralögica, etc..

Vārios são os dispositivos que podem ser empregados na determinação da resistividade de amostras, uns empregandodois e outros quatro eletrodos.

As Figuras 6,7 e 8 e as Fotografias $1,2,3$ mostram - equipamento empregado para a determinação da resistividade de amostras usado no Laboratörio de Geofísica Aplicada, do Departa mento de Geologia, Mineralogia, Física e Matemātica da Faculda de de Filosofia, Ciências e Letras (FFCL) da Universidade de São Paulo (U.S.P.), de Ribeirão Preto. 
A Figura 6 è um corte do dispositivo em escala natú ral, o qual é constituído por quatro partes:

a) dois reservatōrios de solução, cada um contendo dois orifícios para os eletrodos, um para introdução do eletrō lito e outro para saida de ar (Figura 6);

b) porta amostras encaixāvel entre os dois reservatō rios de solução (Fotografia 1);

c) grampo de pressão que mantém o conjunto montado (Fotografia 1).

A Figura 7 mostra o molde e o contra-molde vistos em planta e em corte, em tamanho natural, com indicação do anel de guarda feito com tinta de prata, enquanto a Fotografia 2 refere- se ao molde aberto e o contra-molde de plástico com a amostra.

Os equipamentos eletrōnicos e a distribuição esquemá tica dos mesmos visando determinar a resistividade de amostras estão indicados, respectivamente, na Fotografia 3 e Figura 8.

Este dispositivo emprega a equação I de modo a tornar a ārea da seção da amostra (S) como sendo aproximadamente o do bro do seu comprimento longitudinal, tornando a relação entre es tes dois parâmetros igual a dois, o que facilita os cálculos da resistividade das amostras.

Na Figura 9, são mostrados alguns tipos de dispositi vos empregados para a determinação da resistividade de amostras. 0 dispositivo A é encontrado na obra de HEILAND (1968) com o qual o Autor obteve resultados aceitāveis.

KELLER \& FRISCHKNECHT (1966) analisam o dispositivo B, mostrado na Figura 9, proposto por MAYPER. Embora este disposi tivo tenha sido idealizado com vistas à determinação de fenômé nos de polarização induzida em amostras de rochas, seu emprego po de ser estendido para o estudo da resistividade. Os reservatō rios dos eletrodos de corrente e de potencial são unidos por um fino tubo cuja função é obter uma redução no fluxo de corrente 
atravēs da amostra quando ocorre despolarização dos eletrodos de corrente. 0 fenômeno de despolarização dos eletrodos, explicado por estes dois Autores, pode ocorrer de duas formas: ao ser in terrompida a corrente, fons próximos aos eletrodos de corrente podem combinar-se com os prōprios eletrodos, atravēs de fenōme nos de oxidação ou redução, ou migrar dos eletrodos para a amos tra de rocha. Se o circuito de ligação entre os eletrodos de corrente é completamente interrompido, predominarā o fenômeno inicial, visto o segundo requerer um fluxo de corrente para o seu desenvolvimento.

Uma anālise das figuras 8 e $9 B$ leva-nos a concluir pe 1a superioridade do dispositivo empregado em Ribeirão Preto so bre este proposto por MAYPER, pois KELLER \& FRISCHKNECHT (1966) acentuam que este sistema apresenta o inconveniente dos ruidos elētricos comuns em laboratōrios, o que torna difícil a medida de pequenas diferenças de potencial, devido à resistência elétrí ca apresentada pelo dispositivo.

Esta dificuldade não existe no equipamento empregado por BOGDAN (1976) talvez porque neste modelo os eletrodos de po tencial estejam em contato direto com a solução, o que não ocor re naquele indicado na Figura 6 , e a inexistência do ruf́do deve- se a uma proteção adequada, como a gaiola de Faraday.

No dispositivo $9 C$, que apresenta menor sensibilidade ao ruído, os fenômenos de polarização de eletrodos são mais in tensos (KELLER \& FRISCHKNECHT, 1966). Deve ser considerada, tam bém, a influencia da resistência de contato dos eletrodos (se as paredes das amostras não forem planas) e a condutibilidade super ficial em presença de umidade.

Os arranjos D e E são encontrados em PARASNIS (1973), que sugere a construção $D$ para amostras retangulares, com a re sistividade encontrada pela equação I.

A construção E, sugerida tambēm por PARASNIS, $\bar{e}$ indi cada para a determinação da resistividade de testemunhos de son 
dagens. Dentro de um tubo plástico são presas duas fitas metāli cas de prata ou cobre, com largura de 1 a $3 \mathrm{~mm}$, uma em cada gera triz diametralmente opostas. Dois furos contidos em um circulo são feitos no tubo para a introdução dos eletrodos $M$ e $N$.

Neste dispositivo a resistividade serā:

$$
\rho=\frac{\Delta V}{i} \cdot \frac{b}{k}
$$

onde $\Delta V$ e $i$ são respectivamente a diferença de potencial e a intensidade da corrente medidas, b e o comprimento das tiras metä 1 icas empregadas como eletrodos de corrente, $k \bar{e}$

$$
K=\frac{1}{\pi} \ln \frac{1+\cos \beta}{1-\cos \beta}
$$

e $\beta$ o ângulo indicado na Figura $10 \mathrm{E}$.

0 esquema $F$ indicado na Figura 9 , sugerido por PARASNIS (1956) em PARASNIS (1973), permite a obtenção de valores de re sistividade de amostras com erros de atē $10 \%$, devendo ser evitá do que a distância entre os eletrodos de corrente $A$ e $B$ seja maior que a metade do comprimento da amostra ou menor que a 1 ar gura da mesma.

0 emprego dos dispositivos requer cuidados quanto à resistencia de contato e polarização dos eletrodos, correntes su perficiais e ruidos.

A resistência de contato entre os eletrodos e a amos tra pode ser eliminada empregando folhas de estanho ou de alum $\bar{i}$ nio, grafita em pó ou mercūrio, como sugere HEILAND (1968).

As correntes superficiais provocam erros muito variā veis. Sua origem deve-se à presença de umidade na superfície da amostra, a qual constitui um caminho mais favorāvel à corrente elëtrica que a amostra em si. Segundo BOGDAN (1976), a condução superficial foi eliminada empregando tinta de prata, com a qual. 
foram pintados anēis de guarda nas amostras, como estā indicado na Figura 7. 0 ruîdo decorrente das instalações elétricas pode impossibilitar a obtenção de dados confiáveis quando se determi na a resistividade de amostras, se for empregada corrente alter nada com frequência muito baixa. O ruído constatado em medições com corrente alternada de frequência inferior a $0.3 \mathrm{~Hz}$ foi elimi nado colocando todo o dispositivo dentro de uma gaiola de Faraday.

ORELLANA (1972) sugere que a amostra seja bem maior que as dimensões dos minerais e que, se empregados dispositivos com quatro eletrodos, a distāncia entre os eletrodos de poten cial seja vārias vezes superior ao tamanho dos grãos da rocha, para que as determinações representem a rocha e não alguns mine rais.

\subsection{2 - Profundidade}

A profundidade de investigação por eletrorresistivida de está diretamente ligada ao arranjo de eletrodos empregado,con traste de resistividade entre os diferentes materiais e às condi ções superficiais.

Arranjo de eletrodos

Arranjo de eletrodos é o conjunto deles com os quais è estabelecido um campo elétrico em subsuperfície e medidas dife renças de potencial e intensidade de corrente, na superfície do terreno. Os arranjos são compostos por eletrodos de corrente e de potencial.

Os de corrente são barras ou fios metálicos colocados na superfície do terreno e ligados a uma fonte, a qual fornece 
corrente elētrica que flue atravēs desses eletrodos com uma in tensidade determinada.

Os eletrodos de potencial são colocados na superfície do terreno e são ligados a um instrumento (milivoltĩmetro, poten ciómetro, etc.), que permite determinar a diferença de potencial entre dois pontos. Estes eletrodos podem ser do tipo polariză vel ou não polarizävel.

0 eletrodo polarizāvel è constituído de uma simples barra metālica, enquanto o não polarizāvel ē formado por um reci piente poroso e permeävel (porcelana porosa ou madeira) dentro do qual è colocada uma solução saturada e um fio, ambos do mesmo metal (Figura 10). 0 sal e metal mais empregados são, respecti vamente, sulfato de cobre e cobre metálico.

Os eletrodos de corrente e de potencial podem ser ar ranjados das mais variadas formas. A Figura 11 mostra os arran jos mais usados.

Diversos pesquisadores tem estudado a profundidade de investigação de diversos arranjos de eletrodos. ROY \& APPARAO (1971) estudaram a profundidade atingida por diversos arranjos de eletrodos relacionados na Tabela 2 , tomando por base a defini ção de EVJEN (1938).

EVJEN definiu a profundidade de investigação de um ar ranjo de eletrodos como sendo aquela em que uma fina camada hor zontal contribui com o mäximo do sinal medido na superfície do terreno. Esta definição estā simbolizada atravēs da curva indi cada pela Figura 12 .

A Figura 12 mostra que se $L$ for nulo, o sinal receb $\underline{i}$ do tambēm serā. Aumentando-se $L$ a intensidade do sinal receb $i$ do (i) atinge a um valor mäximo, tendendo a zero para grandes va lores de $L$, pois o sinal proveniente da camada dilue-se naqueles provenientes de outras camadas.

Esta definição ë importante devido ao fato de mostrar 
TABELA 2

VARIAÇAO DA PROFUNDIDADE DE INVESTIGAÇAO EM FUNÇAOO DE L E RESOLUÇAO VERTICAL DE DIVERSOS ARRANJOS

\begin{tabular}{|c|c|c|c|}
\hline \multirow[b]{2}{*}{ Dipolar } & \multicolumn{2}{|c|}{$\begin{array}{l}\text { PROFUNDIDADE } \\
\text { DE INVESTIGAÇAO }\end{array}$} & \multirow{2}{*}{$\begin{array}{c}\text { RESOLUCAAO } \\
\text { VERTICAL } \\
\qquad 1 / 8,4\end{array}$} \\
\hline & 0,35 & $L$ & \\
\hline $\begin{array}{l}\text { Duplo dipolo equatorial }\left(\theta_{1}=\pi / 4\right) \\
\text { ou azimutal }\left(\theta_{1}=\pi / 4\right)\end{array}$ & 0,25 & $L$ & $1 / 5,05$ \\
\hline $\begin{array}{l}\text { Duplo dipolo perpendicular } \\
\left(\theta_{1}=\pi / 4\right)\end{array}$ & 0,20 & $L$ & $1 / 3,8$ \\
\hline $\begin{array}{l}\text { Duplo dipolo polar }\left(\theta_{1}=0\right) \text { ou } \\
\text { radial }\left(\theta_{1}=\pi / 4\right)\end{array}$ & 0,195 & $\mathrm{~L}$ & $1 / 3,45$ \\
\hline Duplo dipolo paralelo $\left(\theta_{1}=\pi / 4\right)$ & 0,18 & $L$ & $1 / 3,1$ \\
\hline Dipolar modificado & 0,18 & L & $1 / 4,35$ \\
\hline Laterolog superficial $\left(0_{1} \mathrm{O}_{2}=0,1 \mathrm{~L}\right)$ & 0,17 & $L$ & $1 / 4,35$ \\
\hline Laterolog superficial $\left(0_{1} \mathrm{O}_{2}=0,2 \mathrm{~L}\right)$ & 0.135 & $L$ & $1 / 4,05$ \\
\hline Schlumberger & 0,125 & $L$ & $1 / 2,45$ \\
\hline Henner & 0,11 & $L$ & $1 / 2,25$ \\
\hline
\end{tabular}


que os conceitos profundidade de investigação e de penetração são diferentes. ROY \& APPARAO (1971) estabelecem esta diferença de vido ao fato de dois arranjos reciprocos um do outro, ou seja, ar ranjos cujas posições dos eletrodos de corrente e de potencial estão trocadas, embora apresentem a mesma profundidade de inves tigação, possuirão correntes de penetração em diferentes graus. Isto se deve ao fato de que a corrente de penetração ē função somente das posições dos eletrodos de corrente, enquanto que a profundidade de investigação e determinada tanto por estes ele trodos como tambëm pelos de potencial (MUSKAT \& EVINGER, 1941).

Em seu trabalho, ROY \& APPARAO relacionam as profund $j$ dades teōricas de investigação, bem como as resoluções verticais de diversos arranjos os quais compõem a Tabela 2. Estes pesquj sadores definiram resolução vertical como sendo o inverso da lär gura da curva que define a profundidade de investigação do arran jo, no ponto onde o valor mäximo $\bar{e}$ a metade.

os valores indicados na Tabela 2, obtidos atravēs de considerações teöricas, mostram que o arranjo dipolar apresenta a maior profundidade de investigação, mas a menor resolução ver tical. A maior profundidade de investigação deste arranjo ē con firmada pela Figura 13, que mostra diversos caminhamentos ele tricos executados com o arranjo dipolar modificado ou laterolog superficial, dipolar e WENNER em um tanque, dentro do qual simbo liza-se um veio condutor. A superioridade do arranjo dipolar con firma as informações teōricas, pois embora $L$ seja metade dos ou tros dois arranjos, a anomalia medida ainda $\vec{e}$ a mais intensa.

A intensidade do sinal recebido, que estä relaciona da à profundidade de investigação, de acordo com a definição de EVJEN (1938), depende tambēm da orientação do arranjo de eletro dos. JAIN (1974) atravess de cälculos teöricos, concluiu que a sensibilidade de arranjos paralelos às estruturas ou caminhamen tos elētricos com o arranjo disposto perpendicularmente à dire ção de movimentação, são mais sensiveis à variação lateral da resistividade; isto porque todos os eletrodos encontram-se no mes 
mo meio. Concluiu tambēm que a forma da curva cóm o primeiro é mais simples que aquela construida empregando-se a segunda confi guração de eletrodos.

A Figura 14, obtida por JAIN (1974) empregando arran jo Wenner com a distância entre os eletrodos extremos (L) 1,5 vezes maior que a espessura de um dique aflorante, ilustra esta conclusão.

\section{Contraste de Resistividade}

0 contraste de resistividade entre os diversos mate riais é importante no estudo da profundidade de investigação de qualquer arranjo de eletrodos, fato mostrado quando são conside rados os dois casos extremos: uma camada perfeitamente condutora ou isolante. Esta camada comporta-se-à como uma barreira, impe dindo que informações abaixo dela sejam obtidas. Nestes casos a profundidade de investigação serä a mesma para qualquer arran jo por mais que seja aumentada a separação entre os eletrodos (EVJEN, 1938).

Embora, teoricamente, o contraste de resistividade en tre os vārios materiais não requeira muitas considerações, exém plos sugerem que materiais cujas resistividades estejam fora de uma adequada relação não são distinguidos, pois são confundidos com o ruïdo.

Assim, quanto mais distantes da superficie do terreno estiverem os materiais investigados, maior deverä ser o contras te de resistividade entre eles, para que ambos sejam determinados. 


\section{4 .3 - Forma}

0 conhecimento da forma do corpo que provoca uma ano malia medida na superficie do terreno, requer o estabelecimento de värios pontos ou perfis de investigação, alēm de conhecimen to adequado sobre a geologia local.

A escolha adequada do procedimento de campo, arranjo e orientação dos eletrodos, baseiam-se na forma esperada do cor po. Assim, corpos condutores aproximadamente esfēricos não são determinados com arranjo de eletrodos Wenner se estiverem a pro fundidade superior ao seu prōprio raio (VAN NOSTRAND, 1953). 
CAPITULO III

3. DEFINIÇÃO E IMPORTÂNCIA DO MODELO REDUZIDO

\section{1 - INTRODUÇÃO}

Modelo reduzido, como o pröprio nome diz, significa uma cöpia em escala menor de um objeto com grandes dimensões,pa ra que possa ser manipulado em laboratōrio. A aplicação deste conceito é muito ütil, permitindo o estudo detalhado do objeto. sem grandes investimentos.

Este conceito é empregado em Geofísica Aplicada na in terpretação dos dados coletados em trabalhos de campo. 0 emprego de modelo reduzido tem por finalidade obter curvas-padrão re ferentes a uma estrutura particular, as quais, comparadas às cur vas reais, permitem a identificação da estrutura em estudo, ou então orientação de campanhas geofísicas (UTZMANN, 1954).

As curvas-padrão, geralmente, são obtidas empregando cālculos matemāticos, graças ao advento dos computadores eletrô nicos. A versatilidade destes é exemplificada por HILL (1972)ao sugerir o uso de tubos de raios catōdicos acoplados a computado res eletrōnicos, com intenção de serem obtidas interpretações mais condizentes com a provāvel estrutura, visto possibilitar que o interprēte compare modelos com os dados obtidos, e os vä modificando atē ocorrer adequada concordāncia entre ambos.

os cālculos matemāticos são mais difundidos que a téc nica de modelos reduzidos por serem mais räpidos e, às vezes, mais precisos e baratos (COGGAN, 1971).

Mas alguns estudos, de acordo com SNYDER (1976), são quase impossiveis de serem executados pela tēcnica matemätica, 
devido à limitação da memōria dos computadores ou aos gastos excessivos com os mesmos. Conclusão anāloga ē dada por MUFTI(1976) ao sugerir o emprego de modelos bidimensionais em cálculos matemāticos em vez de tridimensionais, como solução para não serem utilizados modelos reduzidos no estudo de estruturas com o parâmetro resistividade.

Modelos reduzidos são ūteis portanto, não somente por preencher a lacuna deixada pelo procedimento matemätico,mas também por ser uma tēcnica que, segundo UTZMANN(1954), possibilita o conhecimento de todas as estruturas geológicas.

UTZMANN sugere ainda que modelos reduzidos permitem a construção de um catālogo de curvas-padrão tão completo quanto se desejar, alēm da possibilidade de modificar os modelos até que adequada concordância entre os resultados coletados em laboratōrio e sobre o terreno seja obtida.

Existem, portanto, dois procedimentos - cālculos matemāticos e modelos reduzidos - que se completam. 0 emprego simultâneo alia a versatilidade dos modelos reduzidos com a precisão dos cālculos matemāticos, porque os dados experimentais são corrigidos para a obtenção de curvas isentas de erros.

\section{2 - MODELOS REDUZIDOS PARA MEETODOS SISMICOS}

0 emprego da simulação de estruturas geolōgicas em laboratōrio, embora forneça curvas-padrão precisas, nem sempre satisfaz as condições de rapidez e baixo custo, o que provocou um desinteresse pela tëcnica (CAGNIARD \& NEALE, 1957). Mas atualmen te podem ser desenvolvidas técnicas tanto simples e baratas como complexas e onerosas. As técnicas de maior custo geralmente são aquelas empregadas em mētodos sísmicos, onde hā necessidade de equipamento aprimorado para serem produzidas, recebidas e registradas as vibrações elāsticas. 
DANIEL \& MARINO (1971), empregando uma câmara fotogrāfica Craz-Schardim operando a velocidade de 200.000 exposições por segundo,em modelos constituidos por duas camadas birrefringentes, estudaram o comportamento de ondas refletidas e refratadas; FITZPATRICK (1973) utilizando holografia sísmica analisou as respostas obtidas com diferentes objetos imersos em um cubo de concreto com $1830 \mathrm{~mm}$ de 1ado. Estas pesquisas exemplificam o emprego de delicados e onerosos equipamentos em modelos reduzidos, para estudos sísmicos.

A pesquisa executada por KOEFOED, VAN EWYK \& BAKKER (1958), os quais utilizaram, entre outros equipamentos, gerador de onda quadrada, osciloscōpio e filtro de ruído, ligados em modelos reduzidos simbolizados por faixas de plexiglass, exemplifi ca o suso de equipamentos baratos na ivestigação de ondas refletidas.

\section{3 - MODELOS REDUZIDOS PARA O MÉTODO MAGNETOMÉTRICO}

us modelos reduzidos utilizados no mētodo magnetomētr $\underline{i}$ co geralmente são mais simples e baratos que os usados nos mētodos sísmicos, devido à maior facilidade em produção e registro dos sinais desejados.

As anomalias magnēticas podem ser facilmente estudadas empregando modelos compostos de uma mistura de gesso e magnet ta em pó ou de argila de modelagem, magnetita em pō, ōleo de $1 \mathbf{i}$ nhaça e glicerina, como aconselha PARASNIS (1973). Este mesmo A $\underline{u}$ tor sugere que 0 uso de um par de bobinas de Helmholtz, para criar um campo magnētico uniforme, e um magnetōmetro de saturação, aliados a estes modelos, compõe uma ūtil simulação em laboratōrio para a investigação de anomalias de campo total.

DAVINO (1974) ilustra a facilidade de serem estudadas anomalias magnēticas verticais com auxīlio de modelos reduzidos, 
ao empregā-los com o intuito de obter maior volume de dados às interpretações de uma campanha magnetométrica, executada na faixa Nova Era-Itamarandiba, em Minas Gerais.

Para tanto, foram construidos dois dispositivos, sendo que no primeiro o magnetōmetro era mōvel e, no segundo, fixo, co mo indica a Figura 15.

A Figura 16 (DAVINO, 1974) reproduz um perfil magnetomëtrico obtido sobre um modelo em escala reduzida e um perfil real obtido na ocorrência de Curriolä. Da comparação dos dois perfis, esse Autor conclui que o estudo em modelos reduzidos per mite visualizar o fenōmeno em estudo e, portanto, orientando a interpretação.

GAY Jr.(1963) tambēm afirma que a construção de modelos reduzidos ē muito ūtil, devido à incapacidade da formulação matemätica responder, adequadamente, todas as questões formuladas pelo intērprete durante a anālise das informaçōes coletadas com o mëtodo magnetomētrico.

Esse pesquisador sugere um conjunto para experiēncias em laboratōrio, composto de uma armação de madeira que sustenta modelos constituidos de mistura de cimento, areia e magnetita, em proporções adequadas, e um magnetōmetro Askania GFZ com posição fixa.

GAY Jr. (1963) afirma que foram necessārios três dias e dois individuos para serem coletadas as informações desejadas, estando incluîda tambëm a montagem de todo o conjunto. Com isto, - Autor mostra claramente a facilidade com que è possivel empregar modelos reduzidos com o intuito de solucionar questōes relativas ao mētodo magnetomētrico, dificilmente respondidas pelas formulações matemäticas. 


\section{4 - MODELOS REDUZIDOS PARA MËTODOS ELETROMAGNÉTICOS}

Os métodos eletromagnēticos utilizam uma bobina ou uma combinação de bobinas para produzir um campo eletromagnético e uma outra similar, ou uma combinação, para detectar o campo resultante. Muitas orientações transmissor-receptor são possiveis de serem empregadas.

Embora a aplicabilidade destes mëtodos seja extensa, HOHMANN (1971) sugere que a falta de soluções teōricas para campos dispersos por heterogeneidades tem sido uma das maiores barreiras na difusão do mētodo, falta essa devido as soluções analí ticas resolverem apenas situações que envolvam corpos geomētricos simples, como esferas ou cilindros.

HOHMANN indica o emprego de modelos reduzidos para estabelecer curvas-padrão, com 0 intuito de preencher a lacuna de xada na impossibilidade de utilização de modelos matemäticos.

GAUR, VERMA \& GUPTA (1972) concordam com HOHMANN(1971) com respeito à grande utilidade dos modelos reduzidos para os me todos eletromagnéticos, tanto no estudo detalhado como tambēm no controle minucioso de variāveis e outras condições experimentais simbolizāveis em laboratōrio.

Mas a representação de estruturas geológicas em labora törio, com o intuito de serem investigadas com métodos eletromag nēticos é aparentemente simples, por ser necessärio que no mode10 e estrutura real, o produto $\sigma \omega \mu \ell^{2}$ seja o mesmo, onde $\sigma \bar{e}$ a condutividade em mho.m $\mathrm{m}^{-1}$, $\omega$ é a frequéncia angular do campo eletromagnético empregado, $\mu \bar{e}$ a permeabilidade magnētica para o es paço livre e 1 uma dimensão linear do condutor.

GUPTA, SARMA \& MARU (1971) enumeram algumas dificuldades no emprego desta tēcnica, devido à impossibilidade, por razões prāticas, de ser obtida igualdade nos produtos acima mencio nados: 
- limitação na condutibilidade do material que representarā a rocha encaixante;

- condutores sōlidos dificilmente apresentam a variação de condutibilidade necessāria à simulação de corpos de minērio condutores;

- dificuldade na obtenção de uma fonte muito potente ou receptor adequadamente sensível para que sejam empregadas bobinas transmissora e receptora na mesma escala do experimento.

A remoção destes obstäculos, segundo os mesmos autores, reside no emprego de uma adequada frequência para tornar a igualdade possĩvel e os erros introduzidos pelas dimensões das bobinas podem ser desprezadas desde que o tamanho delas seja muito menor em relação à distância que as separa. Jā $\operatorname{CONEY(1976)~}$ por empregar modelos reduzidos que utilizam como princípio bási co de registro de dados o Geonics EM-16, fabricado pela Geonics Limited, sugere a mudança na condutibilidade, visto este equipa mento empregar frequência na faixa de VLF, o que restringe sua variação.

SPIES (1976) sugere, quando possível, o emprego da re lação entre as amplitudes dos campos secundārio e primārio,vis to não depender das dimensões do modelo.

Os conjuntos de simulação em laboratōrio, empregados em estudos eletromagnëticos, geralmente utilizam, como rocha en caixante, o ar ou uma solução condutora. Os modelos podem ser de vārios materiais condutores, como chapas metālicas (HEDSTRÖM \& PARASNIS, 1958) ou placas de grafita (GAUR, VERMA \& GUPTA, 1972).

\section{5 - MODELOS REDUZIDOS PARA O METODO DA RESISTIVIDADE}

A tēcnica de simulação de estruturas geoiōgicas em la boratörio tambēm comporta-se como importante ferramenta na in- 
terpretação de dados colhidos com o Método da Resistividade,vis to que mesmo formas simples como veios e camadas não aflorantes são dificilmente analisadas atravēs de formulação matemātica (AP PARAO, ROY \& MALLICK, 1969).

Em sondagens elëtricas, este procedimento tem restrito interesse visto importantes conjuntos de curvas-padrão jā terem sido estabelecidos atravēs de cālculos matemāticos. 0 mesmo não ocorre quando é considerada a tēcnica de caminhamento elétrico, visto que as dificuldades apresentadas pela formulação matemāti ca (segundo ORELLANA, 1972), inclusive no estudo de heterogeneidades com forma regular, tem contribuido para o emprego mais fre quente de modelos reduzidos.

Experimentalmente empregam-se mais comumente, três tipos de modelos reduzidos:

a) modelos com papel condutor: é a tëcnica mais simples na investigação de estruturas condutoras com auxîlio de modelos reduzidos. Consiste em empregar pedaços de papel estanho ou aluminio e construir, em escala, a estrutura em anāitise ou pintā-la sobre papel condutor com amalgama de prata. Utilizandose papel condutor, usa-se como cola, tinta chinesa incongelävel quando as resistividades são pequenas e a cola de Filchakov quan do grandes (BLOKH em ORELLANA, 1972).

Segundo ORELLANA (1972), esta tēcnica ē vāilida para es truturas bidimensionais e os resultados obtidos não podem ser ré lacionados diretamente a situações naturais, pois enquanto na na tureza o potencial ē inversamente proporcional à distância,em mo delos reduzidos utilizando-se papel condutor o decrēscimo é 1ogaritmico.

b) ensaios efetuados no terreno, escavando um buraco e preenchendo-o com materiais sōlidos, como areia, argila ou cimen to, dispostos de modo a compor, em dimensões reduzidas, a estrutura que se deseja estudar.

c) experimentação usando tanque com uma solução, den- 
tro do qual, atravēs de modelos confeccionados de vārios materiais, são simbolizadas e analisadas quaisquer estruturas. Este procedimento $\bar{e}$ o mais empregado, embora apresente algumas dificuldades de ordem experimental, entre as quais a escolha de mate riais com a resistividade desejada ē a mais importante.

Esta ültima tēcnica comporta a simulação de outros pro cedimentos elētricos alēm da sondagem e caminhamento elētricos, como o do potencial induzido e da perfilagem elētrica.

AIKEN, HASTINGS \& STURGUL(1973) indicam as trēs tëcnicas para o estudo de fenōmenos de potencial induzido com auxilio de modelos reduzidos. No caso de ser utilizado o tanque, os mode los são constituidos de esponja plāstica porosa com gelatina sal gada no seu interior e imersas em àgua.

ROY \& APPARAO (1976) exemplificam um conjunto para simulação de perfilagem elétrica em laboratörio, analisando o parâ metro resistividade em um tanque. A Figura 17 mostra esquematica mente um corte longitudinal e transversal do tanque com o modelo. Este ūitimo é constituido por uma mistura de areia e cimento.

A importāncia do modelo reduzido na prospecção elētrica ē mostrada por UTZMANN (1954). O autor montou na Compagnie Gé nerale de Géophysique (CGG), um conjunto para experimentação com posto de cuba eletrolitica, ponte rolante para colocação e movimentação dos modelos dentro da solução e um sistema de coordena das para posicionamento dos eletrodos em relação aos modelos.

Com esse conjunto experimental e empregando o arranjo de eletrodos Schlumberger, UTZMANN executou, no perĩodo de 1957 a 1959, vārias sondagens e caminhamentos elētricos sobre estrutu ras complexas, possibilitando à CGG compor, sob a direção de BER TIN, J., em 1970, valiosa coleção de curvas. Essa coleção ē formada por 260 pranchas, das quais 195 são de sondagens elétricas e 65 de caminhamentos elëtricos.

As Figuras 18 e 19 representam sondagens e caminhamentos elētricos executados sobre um cilindro condutor e as Figuras 
20 e 21 sobre um muro resistente cilindrico, as quais ilustram a diversidade na forma dos modelos utilizados por UTZMANN.

CAGNIARD \& NEALE(1957) sugerem o uso de uma placa de acrīlico tocando a superfície da solução da cuba, a qual ē perfú rada segundo uma malha regular que possibilita facilidade maior na localização dos eletrodos, como indica a Figura 22.

Esses autores sugerem este procedimento como uma alter nativa daquele empregado por UTZMANN(1954), embora seja muito trabalhosa a confecção dos furos, os quais não permitem maior $1 \underline{i}$ berdade de posicionamento do arranjo de eletrodos em relação ao mode 10 .

ESTEVES (1966) empregou modelos reduzidos no estudo de estruturas geoiōgicas verticais por sondagens elētricas, utilizando o conjunto experimental sugerido por CAGNIARD \& NEALE(1957) e outro no qual o meio era formado por areia, sendo que a estrutura, um dique vertical, por argila. Os conjuntos possibilitaram confirmar curvas teöricas, embora o emprego do segundo apresente dificuldades na obtenção de materiais com a resistividade deseja da (1 a 1.000 ohm.m) e principalmente, problemas de manuseio.

UTZMANN (1954) apōs estudar värios materiais concluiu pelo uso de um cimento especial chamado "Daro", enquanto APPARAO, ROY \& MALLICK (1969) optaram pelo uso de modelos feitos com uma mistura de cimento e grafita em pó.

0 cimento portland constitui um excelente material para o fabrico de modelos reduzidos, desde que alguns cuidados sejam observados, visto seu endurecimento ocorrer atravēs de reações químicas que persistem ainda depois de transcorrido seis me ses de confeccionado o objeto (BASILIO, 1972). Portanto, qualquer substāncia que altere essas reações pode fazer com que ele comporte-se como uma pilha natural.

A Associação Brasileira de Cimento Portland(ABCP, 1975) recomenda tratamentos especiais em cimentos portland expostos a sulfatos, visto estes provocarem desagregação: silicato de sōdio, 
fluor-silicato de magnēsio ou de zinco, ōleos secantes, cumar, vernizes e tintas, tintas com base de betume ou alcatrão de hulha, alcatrão e breu. Esses tratamentos não são aconselhados a modelos reduzidos por alterarem a composição da solução, como o silicato de sōdio, ou por tornä-los infinitamente resistentes, como os vernizes e tintas.

BASILIO(1976) recomenda tambēm o uso de cimento por tland resistente a sulfatos (tipo "Alto Forno, EB-208" ou o"moderada resistência a sulfatos"), alëm de outros cuidados quando se deseja obter um material resistente à ação de compostos ativos: baixo fator āgua-cimento, amassamento perfeito, adensamento e cura adequados (ABCP, 1969).

0 fator āgua-cimento (fator a/c) estā diretamente 1igado à permeabilidade do cimento, pois a ägua não incorporada às reações quỉmicas tende a evaporar-se, deixando vazio o espaço por ela ocupado. BASILIO(1972) recomenda o uso de fator a/c menor que 0,50 se for desejado um cimento impermeāvel, embora o fator a/c de 0,25 seja o indicado.

0 perfeito amassamento ē recomendado para evitar as porções heterogêneas no modelo. 0 adequado adensamento ē necessärio para que as bolhas de ar sejam eliminadas, melhorando a homogeneidade da pasta de cimento.

0 tempo utilizado na cura do cimento portland desenpe nha função primordial tanto na sua permeabilidade como para evi tar reações quỉmicas. A ABCP (1969) recomenda um perĩodo mínimo de sete dias com o objeto imerso em āgua, se os modelos apresentarem poucas dezenas de quilogramas de peso.

Assim, como vulnerabilidade do cimento portland ē atribuida à sua permeabilidade, alcalinidade e capacidade de seus componentes hidratados suportarem as indesejāveis reações quỉmicas, o uso de um material resistente a sulfatos aliado a baixo fator a/c e grande tempo de cura, torna satisfatōrios os resultados obtidos com seu emprego em modelos reduzidos. 
A variação da permeabilidade do cimento portland com 0 fator a/c, pode sugerir que haja uma interessante variação da sua resistividade com a permeabilidade. BASILIO (1972) fundamentando-se em dados experimentais, sugere que tal variação $\bar{e}$ mais significativa considerando-se a porcentagem de umidade presente.

Estes fatos recomendam o uso de modelos reduzidos satú rados com a solução existente na cuba, para que sua resistividade não varie durante as experiēncias.

Por outro lado, o cimento portland pode ser empregado somente na construção de modelos com resistividades baixas, pois uma argamassa com aproximadamente $10 \%$ de umidade apresenta resis tividade em torno de 200 ohm.m (BASILIO, 1972). 


\section{CAPITULO IV}

\section{LABORATORIO DE GEOFISICA APLICADA DE RIO CLARO}

A montagem de um laboratörio para a execução de expe riências com modelos reduzidos com a finalidade de investigar o parāmetro resistividade, envolve a resolução de dois problemas: equipamento de medidas e modelos reduzidos, sendo o primeiro o mais facilmente solucionado.

\section{1 - EQUTPAMENTO DE MEDIDAS}

0 equipamento de medidas ë formado por dois conjuntos, sendo um deles composto pelos diversos aparelhos eletrónicos e o outro pelas partes não eletrōnicas.

Os aparelhos empregados no Laboratōrio de Rio Claro foram os seguintes:

- resistivímetro modelo AD-71 (Fotografia 4), compos to de bateria de 12 volts, a qual alimenta um conversor $c c / c c$ de 12 volts de entrada e saída de até 500 watts com 0,5 ampere de corrente; e receptor, com circuito eletrônico baseado no poten ciōmetro de schlumberger, para medidas de diferenças de poten cial de 0,01 a 1100 milivolts.

- multímetro eletrōnico modelo PM 2403/03 fabricado pe la Philips.

- osciloscōpio PM 3200 fabricado pela Philips.

As partes não eletrōnicas usadas no Laboratōrio são a cuba eletrolitica, os eletrodos e os cabos isolados.

A cuba eletrolitica usada è uma caixa d'àgua de cimen 
to-amianto, comumente usada como depōsito de āgua, com capacida de para um metro cūbico, com as seguintes dimensões externas: $1460 \mathrm{~mm}$ de comprimento, $1260 \mathrm{~mm}$ de 1 argura e $660 \mathrm{~mm}$ de altura. Dentro da cuba (Fotografia 5) foram instalados três conjuntos: um para movimentação dos eletrodos, outro para sua fixação e o terceiro para fixação dos modelos reduzidos.

A Fotografia 6 mostra a disposição dos elementos que compõem o conjunto de movimentação dos eletrodos:

- volante de ferro fundido com 490 mm de diāmetro;

- duas caixas de ferro fundido para rolamento de $25,4 \mathrm{~mm}$ (1 polegada) de diâmetro;

- uma barra de ferro trefilado de $35 \mathrm{~mm}$ (1 $3 / 8$ de po legada) de diâmetro com rosca de 11 fios em cada $25,4 \mathrm{~mm}$ ( 1 polegada) e extremidades torneadas para $25,4 \mathrm{~mm}$ (1 polegada) para serem encaixadas nos rola mentos;

- uma barra de ferro trefilado de $35 \mathrm{~mm}$ ( $13 / 8$ de polegada) de diāmetro:

- quatro peças de latão para receber o conjunto de fí xação dos eletrodos;

- uma escala de madeira com um metro de comprimento e subdivisões em milïmetros;

- uma haste de 1 atão de $9,5 \mathrm{~mm}$ ( $3 / 8$ de polegada) de diâmetro,para marcar na escala o deslocamento sofri do pelo conjunto de fixação dos eletrodos.

A Fotografia 7 mostra o conjunto de fixação dos ele trodos, onde podem ser vistos:

- placa de acrīlico, em posição superior, com 267 mm de comprimento, $236 \mathrm{~mm}$ de largura e $10 \mathrm{~mm}$ de espes sura, parafusada nas quatro peças de 1 atão; 
- placa de acrîlico inferior, substituível, dotada de furos de acordo com a técnica a ser empregada. A mais utilizada, com furos de 5,6 mm (7/32 de polega da) de diāmetro com centros dispostos sobre uma ma 1 ha regular com $30 \mathrm{~mm}$ de 1 ado, mede $370 \mathrm{~mm}$ de com primento, $337 \mathrm{~mm}$ de largura e $10 \mathrm{~mm}$ de espessura;

- 4 parafusos de 1 atão de $9,5 \mathrm{~mm}$ de diāmetro (3/8 de polegada) com rosca em ambas as extremidades, para fixar a segunda placa à primeira e possibilitar o seu deslocamento vertical conforme as necessidades.

A Fotografia 6 mostra ainda a disposição e as partes que compõem o conjunto de fixação dos modelos reduzidos:

- peça de madeira em forma de "T" invertido, com as dimensões de $620 \mathrm{~mm} \times 60 \mathrm{~mm} \times 65 \mathrm{~mm}$ na sua parte ho rizontal e $350 \mathrm{~mm} \times 80 \mathrm{~mm} \times 40 \mathrm{~mm}$ na parte vertical. Esta possui um rasgo com $12 \mathrm{~mm}$ de largura paralelo à maior dimensão, com a finalidade de permitir movi mentação vertical e inclinação dos modelos reduzi dos. A parte horizontal possui dois furos de $21 \mathrm{~mm}$ (7/8 de polegada) de diāmetro permitindo um des 1 o camento horizontal do conjunto todo; esses furos possuem uma "flange" de $21 \mathrm{~mm}$ (7/8 de polegada) de diâmetro, de cada lado, impedindo que a madeira so fra dilatação com a āguı e impeça a movimentação do conjunto;

- duas barras de ferro redondo trefilado, com $16 \mathrm{~mm}$ ( $5 / 8$ de polegada) de diametro, embutidas em canos de PVC rīgido de $16 \mathrm{~mm}$ (5/8 depolegada) de diāmetro in terno, as quais estão presas à cuba atravēs de "flanges" de $21 \mathrm{~mm}$ (7/8 de polegada) internas e ex ternas. A Fotografia 8 mostra um detalhe dos canos fixados externamente com as barras de ferro trefila do no interior. 
Na Fotografia 9 são vistos os componentes deste con junto e um modelo resistente horizontal fixado.

os eletrodos empregados nos experimentos foram do ti po polarizāvel, visto não ter sido obtido sucesso na construção de eletrodos não polarizäveis. Cada eletrodo ë composto por um pedaço de $56,5 \mathrm{~mm}$ de pipeta $0,1 \mathrm{ml}$, marca Assistent, com um fio de cobre de $0,9 \mathrm{~mm}$ de diāmetro (Fotografia 10). Alguns experi mentos foram executados utilizando-se fio de platina com $0,5 \mathrm{~mm}$ de diämetro substituindo os de cobre, visando comparar estes dois elementos metälicos.

Apoiado na placa inferior do conjunto de fixação atra vēs de um pedaço de borracha que o envolve, cada eletrodo apré senta a extremidade inferior tocando a solução, de modo a originar um menisco. Deste modo, faz-se que todos os eletrodos este jam à mesma profundidade na solução (Figura 23).

os cabos empregados (marca Pirelli, no 18) podem ser substituĩdos por outros mais finos (nümero 24) visto serem util zados pequenos valores de intensijidade de corrente e diferença de potencial.

\section{2 - MODELOS REDUZIDOS}

Os trabalhos de campo em Geofísica Aplicada, na pes quisa de porções determinadas da crosta, encontram situações que podem ser facilmente reunidas em dois grupos: rochas encaixadas e encaixantes. Portanto, no Laboratörio somente utilizam-se es tes dois elementos, procurando representar as diversas situações naturais e manter os contrastes do comportamento elëtrico de ca da elemento. 


\subsection{1 - Rocha Encaixante}

Para representar a rocha encaixante, em modelo reduz do, costuma-se usar uma solução aquosa de um sal. Nos experimeñ tos foi tentado o uso de cloreto de sōdio dissolvido em ägua có mum (de torneira), mas devido a alguns problemas surgidos optou-se pelo sulfato de cobre comercial.

A resistividade da solução de sulfato de cobre sempre foi inferior a 50 ohm.m, em alguns casos próxima de 10 ohm.m.

\subsection{2 - Rocha Encaixada}

A rocha encaixada ē simbolizada com modelos das mais variadas formas e empregando diversos materiais.

Visando facilitar uma representação mais adequada dos modelos eles podem ser agrupados segundo os valores de suas re sistividades em modelos condutores (resistividade inferior a 1 ohm.m), modelos intermediärios (resistividade variando entre 1 ohm.m. e 1.000 ohm.m) e modelos resistentes (resistividade su perior a 1000 ohm.m).

Os modelos condutores foram confeccionados com chapa galvanizada de $2 \mathrm{~mm}$ de espessura com as seguintes dimensões: $660 \mathrm{~mm} \times 400 \mathrm{~mm} \times 65 \mathrm{~mm}$ para simbolizar um corpo com resistivi dade nula, visto que a chapa apresenta resistividade de $10^{-\overline{8}}$ ohm.m (Fotografia 11).

Nas experiēncias realizadas no Laboratōrio de Ribei rão Preto foi utilizado um modelo condutor anālogo, mas com di mensões de $400 \mathrm{~mm} \times 300 \mathrm{~mm} \times 40 \mathrm{~mm}$.

Os modelos resistentes foram confeccionados de made $\mathrm{ra}$, com as dimensões de $600 \mathrm{~mm} \times 300 \mathrm{~mm} \times 37 \mathrm{~mm}$, visando repre 
sentar camadas com as seguintes inclinações: $0^{\circ}, 30^{\circ}, 45^{\circ}, 60^{\circ}$ e $90^{\circ}$. Após a confecção foram pintados para se obter corpos. com resistividade infinita (Fotografia 12).

os modelos resistentes utilizados em experimentos no Laboratōrio de Ribeirão Preto, também confeccionados de madeira, são menores do que os empregados no Laboratörio de Rio Claro. O modelo para representar inclinações de $0^{\circ}$ e $90^{\circ}$ apresenta dimen sões de $380 \mathrm{~mm} \times 310 \mathrm{~mm} \times 38 \mathrm{~mm}$, enquanto os representativos dos àngulos $30^{\circ}, 45^{\circ}$ e $60^{\circ}$ possuem $403 \mathrm{~mm} \times 330 \mathrm{~mm} \times 38 \mathrm{~mm}$.

\section{3 - DISPOSITIVO PARA ELABORAÇÃO DE CARTAS DE ISORRESISTIVIDADE}

Visando obter informações para a composição de uma carta de isorresistividade com modelos reduzidos, foi construído o dispositivo mostrado na Fotografia 13. Seu emprego só possibi lita a execução de caminhamentos elétricos paralelos à maior di mensão da cuba, pois os ortogonais são impedidos pelo conjunto de movimentação dos eletrodos, como pode ser visto nessa Fotogra fia.

Analogamente aos materiais instalados na cuba eletro litica, este dispositivo pode ser dividido em trēs conjuntos: mo vimentação e fixação dos eletrodos e fixação dos modelos reduzí dos (Fotografia 14). Este ūltimo conjunto é o mesmo jā descrito anteriormente.

0 conjunto de movimentação dos eletrodos, mostrado na Fotografia 15, foi construido empregando-se:

- duas barras de ferro perfilado em "T", com $1420 \mathrm{~mm}$ de comprimento e $2,5 \mathrm{~mm}$ de espessura, soldadas nas extremidades em dois pedaços $50 \mathrm{~mm}$ de cantoneiras de ferro. Essas duas barras estão separadas de 42 $\mathrm{mm}$. 
- um carrinho como $\vec{e}$ visto na Fotografia 15 feito com lâmina de ferro de $24 \mathrm{~mm}$ de largura e $4 \mathrm{~mm}$ de espes sura. No centro existe um rasgo com parafuso para a introdução e fixação do conjunto portador dos eletrodos.

o conjunto de fixação dos eletrodos visto na Fotogra fia $16, \bar{e}$ composto de:

- uma lāmina de ferro pintada, de $35 \mathrm{~mm}$ de largura, $4 \mathrm{~mm}$ de espessura e $197 \mathrm{~mm}$ de comprimento que per mite o deslocamento vertical de todo o conjunto;

- uma placa de acrĩlico com $250 \mathrm{~mm}, 110 \mathrm{~mm}$ e $9 \mathrm{~mm}$ com a finalidade de ligar os cabos elētricos aos ele trodos, para que estes ültimos não sofram inclinação;

- uma outra placa de acrílico, colocada em posição inferior, com dimensões variāveis de acordo com 0 arranjo de eletrodos; a placa em uso mede $346 \mathrm{~mm} X$ $107 \mathrm{~mm} \times 9 \mathrm{~mm}$, com furos a cada $15 \mathrm{~mm}$.

0 dispositivo mostrado na Fotografia 17 permite que a placa inferior tenha movimentos de rotação e translação relati vos à placa superior. Estes movimentos possibilitam que os ele trodos tenham as mais variadas orientações em relação à estrutü ra em estudo.

4.4 - ANÁLISE DOS ERROS QUE AFETAM A MEDIDA DA RESISTIVIDADE

Os erros introduzidos nos valores de potencial devido a uma distorção do campo elētrico, podem ser agrupados de acordo com a origem: equipamentos eletrónicos, cuba eletrolítica, solu ção, eletrodos, cabos e modelos.

A Figura 24 representa um caminhamento elëtrico, no qual o ünico erro notado deve-se ao nĩvel de ruĩdo variävel. Es 
ta Figura é tida como modelo para as seguintes, nas quais não se rä representada a parte inferior de cada gräfico. A dimensão $d_{2}$ do modelo representarā o tamanho do lado mais pröximo da superf cie da solução.

\subsection{1-Equipamentos Eletrônicos}

Os equipamentos de campo para a determinação dos valores de resistividade aparente,podem ter os mais variados cir cuitos eletrōnicos. No Laboratörio, os equipamentos utilizados devem ser mais precisos e sensiveis, pois as diferenças de poten cial e intensidades de corrente a serem medidas são pequenas. Dé vido a esse fato o resistivimetro empregado no campo nem sempre satisfaz às condições exigidas pelos experimentos em Laboratōrio.

Assim, o resistivimetro usado no campo pode ser substi tuīdo por vārios equipamentos, inclusive por aqueles que empre gam corrente alternada de baixa frequencia, visando com isso mi norar os efeitos eletroquímicos muito comuns quando è empregada corrente continua.

Por outro lado, os equipamentos podem introduzir ros, desde aqueles devidos a defeitos em seus componentes os causados por condições externas.

Portanto, foram testados alguns resistivimetros, obje tivando escolher o que melhor se adaptasse às exigēncias dos ex perimentos:

- resistivimetro R-50 Stratameter DC fabricado pela Soiltest (Fotografia 18);

- resistivimetro ER-300 fabricado pela Multitron- In dūstria e Comērcio de Equipamentos Eletrōnicos S.A. (Fotografia 19);

- resistivimetro'mode10 AD-71 (Fotografia 4). 
0 resistivimetro $R-50$ Stratameter $\bar{e}$ composto de uma bateria de 12 volts que alimenta um conversor cc/cc com 12 volts de entrada e saîda de ate 112,5 watts com 0,01 a 0,15 amperes e receptor com sensibilidade de 1 a 10.000 milivolts em fundo de escala, com leitura direta.

O resistivimetro stratameter não pode ser utilizado em laboratörio, visto seu conversor apresentar seis teclas, das quais a primeira $j \vec{a}$ correspondendo a uma intensidade de corrente da ordem de $100 \mathrm{~mA}$; esse valor jā $\bar{e}$ elevado se comparado aos $5 \mathrm{~mA}$ geralmente tidos como elevada intensidade de corrente.

0 resistivimetro ER-300 é composto de bateria de 12 volts que alimenta um conversor cc/cc de 12 volts de entrada e saîda de atē 80 watts, com um ampere de intensidade de corrente; - receptor é para leituras diretas de 3,16 a 1000 milivolts, em fundo de escala. Este aparelho foj empregado no Laboratōrio de Ribeirão Preto e comportou-se muito bem durante os experimentos.

0 resistivĩmetro $A D-71$, de grande potência, apresenta alta sensibilidade no seu circuito potenciomëtrico, permitindo o seu emprego em laboratōrio. Mas tal não ocorreu satisfatoriamen te devido a problemas eletrōnicos. Tais problemas consistiram em:

- o conversor, alēm de apresentar instabilidade na in tensidade de corrente produzida, dificultando as leituras de intensidade de corrente e diferença de potencial, pode mostrar erros negativos superiores a $30 \%$, se comparado ao valor lido em um multimetro eletrōnico;

- no receptor foram constatados problemas de oxidação em suas chaves, devido ao longo tempo que o instru mento permaneceu inativo. Alēm desse fato constata ram-se erros nas medidas de diferença de potencial, atribuĩdos a erro de cālculo quando da montagem do aparelho, devido à baixa qualidade das resistēn 
cias empregadas na montagem das três dēcadas (os va lores marcados nas resistências podem variar de até $10 \%)$. Um teste executado constatou a existencia de erros positivos variando entre $4 \%$ e $10 \%$ entre as diferenças de potencial lidas no receptor e em um multimetro eletrōnico.

Por outro lado o resistivimetro $A D-71$, em termos de construção, apresenta uma grande vantagem: seu amplificador ope racional possui quatro transistores (dois deles BC 108 e dois AC 184) facilmente encontrāveis para substituição caso apresen tem alguma irregularidade. Alēm deste fato, um potenciōmetro ga rante um perfeito equilibrio entre esses componentes, pois tais transistores nem sempre possuem características idénticas.

Um erro muito comum nas medições feitas em laboratō rios è causado pela umidade, visto provocar variações no compor tamento físico dos componentes eletrōnicos. Sua eliminação $\bar{e}$ simples, bastando acondicionar os equipamentos em um armärio com aquecimento interno. Erro tambēm comum evidenciado por equipamentos que
utilizam corrente continua ou corrente alternada de baixa fre quência, è devido à influēncia das instalações elëtricas do labo ratōrio, a qual pode ser eliminada ligando um fio terra do apare Tho ao polo negativo da instalação elëtrica ou então ligando-o a um polo terra construído com cuidado.

- Laboratório de Geofísica Aplicada de Ribeirão Preto emprega equipamentos eletrōnicos muito sensiveis, para os quais foi necessārio enterrar profundamente uma barra de cobre imersa em cloreto de södio comercial, visando com isso obter um poloter ra adequado. Alēm disso, parte do equipamento encontra-se den tro de uma gaiola de Faraday.

os ruĩdos notados nas medidas não podem ser atribui dos unicamente ao mau funcionamento de um componente eletrónico do equipamento em operação. Isto porque a intensidade da corren 
te utilizada desempenha função importante na precisão dos dados coletados. Experimentos mostraram que devido ao elevado nível de ruïdo existente em laboratōrio, o sinal enviado pelo resisti vïmetro tambëm deve ser elevado, para que a diferença de poten cial medida represente adequada relação sinal-ruído, embora o re ceptor possua circuito para compensar diferenças de potencial prē-existentes.

A Figura 25 representa dois caminhamentos elétricos, executados com o modelo condutor na horizontal e situado a $120 \mathrm{~mm}$ de profundidade, utilizando-se arranjo wenner $(A M=30 \mathrm{~mm}) . \quad A$ curva 1, obtida usando $0,7 \mathrm{~mA}$ de intensidade de corrente, apre senta uma variação maior que na curva 2, para a qual empregou-se intensidade de corrente variando em torno de $3 \mathrm{~mA}$, mostrando as sim a importância deste fato.

As Figuras 26 e 27 representam quatro caminhamentos elētricos que evidenciam a somatōria de duas fontes de erros: equipamento defeituoso e baixa intensidade de corrente. Uma ba teria comum de automövel utilizada comofonte para o conversor, apresentou um vaso defeituoso, não fornecendo os 12 volts neces särios, enquanto a intensidade de corrente utilizada situou-se em torno de 1,2 mv. A Figura 28 mostra dois caminhamentos elētri cos executados nas mesmas condições, mas sem a presença das citá das fontes de erros.

4.4 .2 - Cuba Eletrolitica

A cuba eletrolitica $\vec{e}$ outro componente que provoca dis torções no campo elëtrico estabelecido, devido suas paredes se rem isolantes.

Essas distorções são proporcionais não apenas à proxi midade dos eletrodos à parede, mas tambëm ao seu espaçamento, ao seu āngulo com a parede, dependendo tambēm da resistividade da parede e da sua forma. 
GOUDSWAARD (1957) analisou teörica e experimentalmen te os efeitos causados pelas paredes de uma cuba em experimentos. A Figura 29 mostra a influência de paredes isolantes e conduto ras nas medidas de resistividade. Empregando arranjo de eletro dos Wenner, perpendiculares à parede da cuba, e dois espaçamen tos, constatou que paredes isolantes tendem a influir com maior intensidade que as condutoras.

Em seu trabalho o autor conclui que uma parede de "perspex "coberta por uma tela de latão (malha quadrada com $2 \mathrm{~cm}$ de lado, construída com fio de latão de $4,55 \mathrm{~mm}$ de espessura)pro duz efeitos despreziveis à distância superior a $50 \mathrm{~mm}$, mesmo em pregando espaçamento de $100 \mathrm{~mm}$ entre dois eletrodos consecutivos.

A cuba : empregada no Laboratōrio de Rio Claro possui paredes teoricamente isolantes, com ondulações para aumentar a sua resistência física às tensões existentes quando estä cheia. Tal fenōmeno deve provocar uma distorção ainda mais irregular no campo elëtrico.

Visando determinar a influência das paredes, foram executadas algumas experiências. A Figura 30 mostra os resulta dos obtidos empregando-se arranjos Wenner e schlumberger perpen diculares e paralelos à parede menor da cuba, para os quais fó ram consideradas distāncias mēdias, ou seja, aquela que seria ob tida se a parede não apresentasse as citadas ondulações.

A anāilise desta Figura indica que os arranjos são tan to mais sensiveis aos erros introduzidos pela cuba, quanto maior for o espaçamento entre os eletrodos e quanto mais prōximos da perpendicular à parede, estiverem os eletrodos.

A Figura 31 mostra uma sondagem elētrica executada no Laboratório de Rio Claro com o intuito de investigar a influên cia das paredes da cuba nos dados experimentais.

Fato interessante é obtido ao serem comparadas as for mas das curvas relativas ao arranjo Wenner nas Figuras 29 e 30 . Constata-se que a cuba empregada no Laboratōrio de Rio Claro 
apresenta um comportamento intermediärio, talvez devido ao abaj xamento da resistividade do cimento-amianto em presença do sulfa to de cobre na parede (coloração azulada vista na Fotografia 6). E evidente que esta parede não pode ser comparada àquela obtida por GOUDSWAARD ao combinar o material isolante com a malha metā lica, o que the confere superioridade sobre o cimento-amianto.

A Figura 32 mostra um caminhamento elëtrico no qual a influência das paredes não é notada.

A Figura 33 mostra um caminhamento elētrico no qual a influēncia das paredes è notada somente nas porções externas da curva, não havendo portanto erros nos valores de anomalia.

\section{$4.4 \cdot 3-$ Solução}

A representação da rocha encaixante è muito importante visto ser ela o suporte para o estabelecimento do campo ele trico. Este material deve apresentar algumas características:

a) fácil manuseio, pois serão colocados outros mate riais em seu interior que representarão a rocha en caixada, em posições espaciais prë-estabelecidas. Alēm deste fato, deve ser considerado o contraste elëtrico entre as duas rochas que deverā ter um va lor determinado. Assim, o uso desse material deve rä facilitar tanto a obtenção do contraste elëtrí co desejado como tambēm a colocação da rocha encai xada em seu interior.

b) Permitir a obtenção de um meio isōtropo para que qualquer variação de resistividade seja decorrente da presença do modelo.

c) Apresentar um perfeito contato elëtrico com o mode 10 em seu interior. 
d) Tornar desprezível a resistência de contato e a po larização dos eletrodos.

e) Custo relativamente baixo.

Assim, foi preferido o emprego de uma solução aquosa. A primeira vista, seria a ägua destilada o solvente mais adequa do, e como soluto, algum sal com satisfatōria pureza química. Mas tal fato não ocorre, pois, com o tempo, as impurezas do ar, das mãos do operador e do prōprio tanque, vão tornando a solução im pura. Aliada a estas desvantagens deve ser considerado o alto custo de qualquer soluto quimicamente puro e a demora de obten ção de tal quantidade de āgua destilada. Portanto, optou-se pé la ägua de torneira como soluto e de algum sal comercial como cloreto de södio ou sulfato de cobre, tambëm porque diversos Au tores obtiveram bons resultados.

No Laboratōrio de Ribeirão Preto foi empregado com bons resultados o sulfato de cobre, mas no inicio do funcionamen to do Laboratōrio de Rio Claro, foi experimentado o cloreto de sö dio.

Este soluto não permitiu a obtenção de bons resulta dos devido à polarização dos eletrodos e ao ruĩdo de fundo, favo recidos pela baixa resistividade da solução preparada. A Figura 34, exemplificando estes fatos, representa um caminhamento ele trico sem modelo imerso, empregando eletrodos com fio de platina de $0,5 \mathrm{~mm}$ de diâmetro e uma solução de cloreto de sōdio. Esta Figura mostra tambēm a tendência de aumento da resistividade apa rente medida, causada possivelmente pela parede da cuba em um meio tão condutor.

Como em experiências realizadas no Laboratörio de $\mathrm{R} \dot{i}$ beirão Preto empregou-se sulfato de cobre, optou-se pelo seu uso tambēm no Laboratōrio de Rio Claro para serem mantidas condições anālogas.

Para tanto, foram executadas medidas com um condutivi metro, modelo E 382 fabricado pela Metrohm, para determinar a vá 
riação da resistividade da solução com a temperatura e quantida de de sulfato de cobre dissolvido, cujos resultados permitiram a construção da Figura 35. Na preparação das soluções, com as quais obtiveram-se os dados necessärios para traçar as retas, em pregou-se sulfato de cobre comercial e ägua da rede pūblica de distribuição.

A resistividade da solução è um importante fator em modelos reduzidos, não tanto por seu valor absoluto, mas princi palmente sua homogeneidade. Experiências mostraram que alguns cuidados devem ser observados para que a homogeneidade no valor da resistividade da solução, dentro da.cuba, seja obtida:

a) não permitir o estabelecimento de um gradiente tē $\underline{r}$ mico,atravēs da montagem da cuba num local ondé não fique exposta ao sol e longe de qualquer equi pamento que gere calor;

b) evitar contaminações da solução por öleos, por que estes formam uma pelicula superficial que induz erros. Portanto, devem ser tomados cuidados duran te a lubrificação do conjunto de movimentação dos eletrodos para evitar essa fonte de erros;

c) não permitir que se forme película de poeira sobre a superfĩcie da solução, o que tambëm produz erros nos valores obtidos;

d) filtrar a ägua antes de colocā-la na cuba, para re tirar partículas em suspensão (argilas e outras substāncias), as quais afetam a homogeneidade do valor da resistividade;

e) impedir a circulação de ar dentro do Laboratörio, a qual provoca movimentação da superficie do lĩqui do e instabiliza as leituras de diferença de poten cial.

Durante os experimentos, foram constatados alguns fa 
tos:

a) apōs o decurso de um período de 14 a 16 horas, hä formação, na superfĩcie da solução, de uma pelĩcu la vîtrea azulada, possivelmente de sulfato de có bre, originada pela evaporação da āgua. Este fenó meno foi notado todas as manhãs ao serem iniciados os trabaihos. A retirada desse material, necessa ria porque provoca erros nas medidas, ē obtida pas sando, na superfície do líquido, um pedaço de madej ra. O precipitado aderido à madeira è retirado fa cilmente pela água corrente da torneira;

b) no fundo da cuba nota-se a formação de um precipi tado de cor verde-musgo. Esse material deve ser proveniente da reação do sulfato de cobre com os sais presentes na ägua canalisada, fato notado no esvaziamento da cuba e consequente limpeza, pois durante seu reenchimento e adição de sulfato de co bre ocorre um leve turvamento da solução. A esté precipitado deve ter se juntado a poeira caída den tro da cuba;

c) com o passar dos dias, a resistividade da solução aumenta, tendo sido constatados valores superiores a 100 ohm.m em soluções cuja resistividade inicial era aproximadamente 10 ohm.m. Esta diminuição da condutibilidade deve-se, talvez, à precipitação do sulfato de cobre junto com a poeira e sais e à for mação da pelīcula superficial. BOGDAN (1976) jä encontrou valores superiores a 800 ohm.m;

d) ao ser acrescentada āgua de torneira para aumentar a resistividade da solução, notou-se que o aumento ē pequeno, mesmo que metade do volume da soluçãose ja substituĩdo pela referida āgua. Ao ser feita a substituição, a solução deve ser agitada para se obter a homogeneização, ocasião em que se verifica 
a movimentação do precipitado existente no fundo da cuba. Como a resistividade da solução sofre alte ração muito pequena, supõe-se que parte do precipi tado seja dissolvido, elevando a condutibilidade.

Outra fonte de erro que deve ser considerada $\overline{\mathrm{e}}$ a exis tência de objetos metālicos no interior da solução. Is to ocorre devido ao fato da solução ser um meio adequado a reações quími cas, pois o sal dissocia-se em um ācido e uma base. Esta dissó ciação quîmica torna-se mais complexa devido à āgua de torneira utilizada, que alēm dos sais normalmente contidos em uma āgua po tāvel comum, ainda carrega traços dos produtos químicos usados no seu tratamento.

Portanto, um objeto metālico colocado na solução, nor malmente reage com ela. Exemplo desse fato, ocorrido no Laborá tōrio de Ribeirão Preto, $\bar{e}$ visto na Fotografia 20 , na qual são notadas as barras de aluminio, sobre as quais movimentam-se os suportes dos modelos, com evidentes sinais de oxidação.

Para evitar esta oxidação, que dificulta a movimenta ção das hastes de fixação dos modelos reduzidos, as barras metā licas devem ser colocadas dentro de tubos plāsticos, o que foi executado quando da montagem do Laboratōrio de Rio Claro, como ē visto na Fotografia 9.

A Figura 36 mostra três caminhamentos elētricos execu tados no Laboratōrio de Rio Claro, utilizando-se arranjo de ele trodos Wenner com três espaçamentos, sem a presença de modelos reduzidos. Evidencia-se a homogeneidade elētrica da solução e à nãoconstatação de erros introduzidos pelo conjunto de fixação dos modelos reduzidos, embora sejam notados efeitos do ruido nos valores medidos. 
4.4.4-Eletrodos

Os eletrodos utilizados em experimentações com mode los reduzidos podem ser do tipo polarizāvel, embora seja aconse Ihävel o uso do tipo não polarizävel, pois os primeiros podem apresentar alguns inconvenientes como polarizaça e eletrōlise do metal.

Inicialmente pretendeu-se construir eletrodos não po larizāveis, com o intuito de eliminar os efeitos citados, utili zando uma caneta hidrocolor, que ē fabricada em sērie, o que as torna razoavelmente iguais (Fotografia 21 ).

Tal construção não obteve sucesso face à alta permea bilidade da pena, impedindo que a solução permanecesse dentro do recipiente alëm de vinte minutos. Visando impedir o escoamento da solução, impermeabilizou-se parcialmente a pena com vaselina, sem obter melhora sensĩvel nas condições de trabalho.

Assim, decidiu-se pelo uso de eletrodo polarizāvel, o qual apresenta os $j \vec{a}$ referidos inconvenientes da eletrölise e polarização.

os primeiros experimentos realizados no Laboratōrio de Ribeirão Preto evidenciaram os erros introduzidos nas medidas provocados pelo desgaste dos eletrodos metālicos e uso de inten sidade de corrente superior a alguns miliamperes como è visto na Figura 37.

os desgastes dos eletrodos são causados pela eletrōl se dos fios metālicos originada pela corrente continua. Assim, apōs alguns ensaios, o eletrodo A (polo positivo) apresenta-seme nor que o B; e transcorridos mais alguns ensaios, o eletbodo $\bar{M}$ (polo positivo) tambēm apresenta-se menor que $0 \mathrm{~N}$.

Esta diminuição gradativa dos eletrodos resulta em re dução da intensidade de corrente e consequente diminuição da di ferença de potencial, alterando as condições experimentais com 
a introdução de erros.

A diminuição gradativa pode ser acelerada com o empre go de intensidades de corrente superiores a alguns miliamperes, alēm de ser iniciada eletrōlise da āgua. Na eletrōlise,as bo lhas de gās comportam-se como materiais isolantes, envolvendo os eletrodos de corrente e provocando variações nas intensidades de corrente, originando, assim, erros nas determinações da resis tividade aparente.

Estas duas fontes de erros - eletrōlise da āgua e dị minuição dos eletrodos - podem ser eliminadas com a utilização de intensidades de corrente suficientemente baixas para que não ocorram, mas tão elevadas para que a relação sinal-ruĩdo permane ça adequada.

Experimentações indicaram que a intensidade de corren te adequada varia proporcionalmente com a resistividade da solú ção e,principalmente, com as dimensões do arranjo utilizado,como tambēm do nīvel de ruīdo, o qual é variāvel durante o experimen to. Assim, para as resistividades da solução compreendidas entre 10 e 50 ohm.m e arranjos de eletrodos Wenner com distāncias en tre dois eletrodos consecutivos variando entre 30 e $100 \mathrm{~mm}$, obt veram-se bons resultados com o uso de 2,0 a 4,5 mA.

Como o nīvel de ruīdo oscila, não é desejāvel o empre go de intensidades de ocorrentes inferiores a $2 \mathrm{~mA}$, sob pena de serem obtidas informações que representem uma somatōria da varia ção do ruỉdo e da resistividade aparente, enquanto valores supé riores a 4,5 mA provocam eletrōlise da āgua e dos eletrodos.

A Figura 38 representa um caminhamento elētrico execu tado, para o qual a intensidade de corrente adequada foi aprox $\bar{i}$ madamente $4 \mathrm{~mA}$.

Assim, no início das experiēncias no Laboratōrio de Rio Claro, foram construídos eletrodos polarizāveis com fio de platina visando eliminar completamente os erros introduzidos pe la eletrōlise do fio de cobre. Mas o emprego da platina $\bar{e}$ desa 
conselhāvel visto ser a polarização e ruĩdo captado muito eleva dos, podendo atingir, somando-se ambos, valores superiores a $1500 \mathrm{mv}$, enquanto com o cobre registrou-se um māximo de $300 \mathrm{mv}$.

OGILVY, AYED \& BOGOSLOVSKY (1969) agitando eletrodos metälicos em ägua destillada e medindo a diferença de potencial obtida, encontraram para cobre, prata e platina, respectivamente, $26 \mathrm{mv}, 33 \mathrm{mv}$ e $95 \mathrm{mv}$. Estes valores confirmam, portanto, a con clusão de não ser aconselhado o emprego de eletrodos de platina e corrente contĩnua.

Em experiências de laboratōrio constatou-se que as di ferenças de potencial medidas com eletrodos sem ponta são meno res que com ponta. Este fenômeno patenteou-se pela impossibili dade de ser executado um caminhamento elétrico com arranjo Schlumberger $(A B=300 \mathrm{~mm}, M N=20 \mathrm{~mm})$ com os eletrodos sem pon ta. Esta impossibilidade ocorreu devido ao fato de intensidades de corrente superiores a $5 \mathrm{~mA}$ provocarem diferenças de potencial abaixo da sensibilidade do equipamento empregado ( 1 milivolt). Mas com eletrodos com $1 \mathrm{~mm}$ de ponta, este experimento pode ser realizado com intensidade de corrente em torno de $2 \mathrm{~mA}$.

Constatou-se tambëm que eletrodos com atē $2 \mathrm{~mm}$ de pon ta não provocam erros nas medidas, desde que os comprimentos das pontas sejam aproximadamente iguais, pois experimentos realiza dos por UTZMANN (1954) sugeriram que erros de $0,5 \mathrm{~mm}$ no aprofun damento dos eletrodos na solução provocam variações de $1 \%$ nas resistividades aparentes medidas.

A Figura 39 mostra dois caminhamentos elétricos execu tados sob as mesmas condições, mas a curva 1 obtida com eletrodo sem ponta e a 2 com os eletrodos apresentando $1 \mathrm{~mm}$ de ponta.

4.4 .5 - Cabos 1 solados

Os cabos isolados devem ser de boa qualidade quando 
usados no campo, para que não ocorra fuga de corrente ou rompj mento, visto que são arrastados no chão.

No laboratōrio o isolamento dos cabos ē mais importan te, pois estes são usados pröximos de um meio condutor. Assim, qualquer defeito no isolamento plástico pode provocar erros nas medidas.

$4.4 .6-$ Modelos

A resistividade dos modelos foi dividida em três gru pos, conforme o contraste de sua resistividade com a solução se ja inferior, igual ou superior à unidade.

Os modelos com resistividade menor que a da solução são aqui chamados de condutores, enquanto aqueles cuja resistivi dade é mil vezes maior que a da solução é chamado de isolante.

os modelos isolantes podem ser construidos com madei ra, plästicos em geral ou isopor, em virtude das seguintes vantagens:

- resistividade praticamente constante. No caso de madeira, basta revestīla de algumas camadas de tinta a öleo para que sua resistividade não varie quando introduzida na solução;

- fäcil manuseio e aquisição do material;

- baixo custo(principalmente).

A madeira, representando modelos resistentes, não apre senta inconveniente algum, excetuando a pintura requerida para que sua resistividade seja constante. Este cuidado deve ser to mado visto que suas permeabilidade e porosidade não são homogê neas, existindo zonas nas quais a solução penetrarā mais, provo cando variação da resistividade em partes do modelo. 
Esta heterogeneidade na variação de resistividade do modelo poderä ser desprezĩvel se a madeira for relativamente ho mogènea e o modelo pequeno.

Alëm deste caso extremo (modelo resistente ou resisti vidade infinita) pode ser estudado o outro extremo, modelo condu tor (resistividade nula), feito de metais. 0 uso de chapas de ferro galvanizado, devido ao baixo custo e excelente condutibi lidade, è recomendado.

A chapa de ferro galvanizado, assim como qualquer ou tro metal, reage com a solução, mais ainda quando submetida a um campo elétrico gerado por corrente continua. 0 modelo coridutor visto na Fotografia 11 apresenta zonas mais claras que ilustram portanto o fenōmeno de interação quỉmica modelo-solução, enquan to a Figura 40 mostra o efeito dessa interação química nas medi das de resistividade aparente.

Para evitar semelhante inconveniente seria necessārio o emprego de metais não reativos como o ouro, platina ou em $\bar{u}$ ti mo caso o cobre. 0 emprego destes metais ē problemātico devido aos custos dos materiais e confecção dos modelos, principalmente considerando os dois primeiros.

Entre estes contrastes extremos de resistividade po dem ser intercalados infinitos valores, variando não somente a resistividade dos modelos atravēs do emprego de värios materiais, como tambëm variando o conteüdo de sulfato de cobre na solução,o que provocarā variação na resistividade da mesma.

Alëm de metais e madeira, outros materiais podem ser usados, como o gesso e o cimento.

APPARAO, ROY \& MALLICK (1969) experimentaram värios ma teriais, obtendo sucesso empregando uma mistura de cinco partes de cimento e seis de grafita. Modelos constituídos dessa mistu ra apresentaram resistividade de 0,18 ohm.m se embebidos tota 1 mente por solução.com 16 ohm.m. 
Estes Autores afirmaram que experimentos com gesso não permitiram a obtenção de bons resultados. Nas experiências realizadas no Laboratōrio de Ribeirão Preto por BOGDAN, A., su geriram que gessos especiais podem ser usados com sucesso, prin cipalmente aqueles utilizados para modelagem de dentaduras. Esse pesquisador concluiu tambēm que a porosidade e a permeabilidade do gesso relacionam-se diretamente à quantidade em peso de ägua utilizada para sua hidratação, constituindo $30 \%$ em peso a quan tidade de ägua ōtima para esse fim. Mas esses gessos especiais tem como inconveniente o alto custo.

\section{5 - IMPORTÂNCIA DA ESCALA NOS MODELOS REDUZIDOS}

Estudos geofisicos com auxilio de modelos reduzidos podem ser executados e estendidos às situações naturais desde que as dimensōes dos modelos, configuraçöes de eletrodos e os con trastes de resistividade entre os materiais representados no la boratörio sejam proporcionais àqueles encontrados em situações reais.

Essa redução implica numa incerteza em manter as rela çöes corretas, incerteza que ao redor de $5 \%$ pode ser negligencia da por ser inferior äquela normalmente encontrada em prospecções no campo (UTZMANN, 1954).

Alēm dos erros experimentais, deve ser considerada a escala de representação dos dados. Estalpermite uma tolerāncia maior nas incertezas experimentais ou então um rigor maior. E necessärio, portanto, adequar as escalas de redução do conjunto experimental com a de representação gräfica dos dados obtidos, visto haver uma relação direta entre os custos na montagem de to do laboratörio e a precisão desejada.

0 conjunto experimental instalado no Laboratörio de Rio Claro devido ao custo e dimensõesreduzidas pode ser conside rado como uma representação na escala de 1:5.000. 
CAPITULO $\mathrm{V}$

\section{EXPERIENCIAS DE LABORATORIO}

Algumas experiências foram executadas com o intuito de analisar diversos modelos e equipamentos, bem como para determinar a aplicabilidade dos mesmos. Assim, foram estudados alguns modelos resistentes visando comprovar experimentalmente algumas considerações teōricas e testar o dispositivo para o levantamento da carta de isorresistividade, além de ensaios para emprego de modelos reduzidos no estudo de fenōmenos de polarização expon tânea.

5.1 - VERIFICAÇÃO EXPERIMENTAL DE ALGUMAS CONSIDERAÇÕES TEÓRICAS

JAIN (1974), utilizando formulação teōrica, concluiu que o arranjo de eletrodos Wenner disposto perpendicularmente à direção do caminhamento, apresenta maior sensibilidade para as va riações de resistividade e a curva resultante é mais simples do que aquela obtida com o paralelo, supondo que o caminhamento elé trico é executado perpendicularmente à direção geral das estrutú ras. Esta conclusão foi verificada atravēs da experimentação com modelos reduzidos.

A Figura 4 ? mostra que a superioridade atribuida por JAIN (1974) ao primeiro procedimento não ē tão marcante como vis ta na Figura 14, devido o modelo não estar aflorando na superfície da solução.

A Figura 42 representa a mesma situação e evidencia que corpos não aflorantes não provocam muita diferença nos dados obtidos com os dois procedimentos, exceto na forma das curvas. 
Evidencia tambëm que essa diferença marcante deve ocorrer somente para corpos aflorantes, visto que corpos mais profundos contribuem apenas na obtenção de anomalias mais amplas quando os eletrodos estão paralelos à direção de movimento.

Outra experiencia foi executada com o objetivo de veri ficar se corpos condutores são mais facilmente determinados que os isolantes. A comparação entre as Figuras 42 e 43 evidencia que a proposição é valida somente para corpos situados a profundidades inferiores à sua espessura, visto que em profundidades maiores as amplitudes de ambas as curvas tendem a igualar-se.

5.2 - APLICABILIDADE DA ANÄLISE DE TENDÊNCIA EM MODELOS REDUZIDOS

Dentre os experimentos executados, destaca-se aquele com a finalidade de verificar a aplicabilidade da anāise de ten dência aos dados obtidos na cuba. Esta experiência, executada a pedido de BOGDAN, $A$., mostrou resultados interessantes, indicando que esta anālise é aplicāvel aos dados coletados no laboratório.

Para tanto, foram utilizados modelo resistente horizon tal à profundidade de $40 \mathrm{~mm}$, arranjo de eletrodos Wenner (AM = $60 \mathrm{~mm}$ ) e o dispositivo para carta de isorresistividade. Os dados obtidos, processados por BOGDAN, compõem as Figuras 44 e 45.

\section{3 - POTENCIAL EXPONTÂNEO}

Na natureza podem-se apresentar diferenças de potenclal entre dois pontos, geradas por fenōmenos eletroquímicos, em bora as teorias existentes não expliquem satisfatoriamente o pro cesso de origem (ORELLANA, 1972). Valores anōmalos medidos têm como origem tanto a movimentação da āgua como a presença de cor 
pos sulfetados.

As diferenças de potencial originadas pela movimentação da āgua são estudadas com finalidades diversas. 0s valores anômalos de potencial, utilizados em perfilagens elētricas para a determinação da porosidade das rochas, baseia-se na movimenta ção diferencial apresentada pelos ions, quando dois fluxos de āgua com composições quỉmicas diferentes entram em contato.

Diferenças de potencial são tambēm originadas pela mo vimentação da āgua em subsuperfície, a qual provoca tais diferenças em decorrência da eletro-filtração. Este fenōmeno tem origem na retenção dos ânions junto às partīculas que compõem as rochas e movimentação dos cātions com a solução. Como este fenōmeno è tanto mais intenso quanto maior for o fluxo da āgua subterrânea, conclui-se que materiais com alta permeabilidade favorecem o aparecimento de elevadas diferenças de potencial.0s potenciais de eletrofiltração são empregados com sucesso na determinação de pontos de fuga de āgua em barragens.

As diferenças de potencial naturais, de maior interes se na mineração, são aquelas encontradas prōximas a corpos sul fetados. Diversos pesquisadores tem estudado o fenōmeno, mas a hipōtese mais aceita atualmente ēa de SATO \& MOONEY (1960), a qual explica que o potencial natural encontrado em corpos sulfe tados deve-se a existência de reações diferentes na rocha encai xante acima e abaixo do nīvel freātico, entre as quais o corpo de minērio sulfetado comporta-se como condutor de eletrons. De vido às diferentes condições físico-químicas existentes acima e abaixo do nível do lençol freático, na parte superior as subs tâncias dissolvidas captam elētrons do corpo de minērio e na in ferior essas soluções cedem os elētrons ao corpo.

A interpretação das informações obtidas pelo mëtodo de polarização expontānea, geralmente ē feita atravēs de cālcu los matemáticos. Visando estudar a aplicabilidade dos modelos reduzidos como ferramenta nas interpretações, foram executadas 
experiēncias objetivando a montagem de um dispositivo para a de terminação de curvas-padrão.

Inicialmente foi preparada uma solução relativamente condutora (10 ohm.m) que serviria como meio para a criação do campo que representaria o potencial expontāneo medido na rocha encaixante.

Como primeiro teste foi imersa, na solução, uma pilha comum de rädio tipo AAA. Não foi obtido sucesso pelo fato da corrente elētrica escoar-se atravēs da blindagem metālica, fato evidenciado pela deposição de um precipitado, alguns minutos após ter sido merguihada.

Visando permitir que apenas os polos negativo e positi vo ficassem em contato com a solução, a pilha foi colocada den tro de um tubo de PVC rígido com $47 \mathrm{~mm}$ de comprimento e $16,2 \mathrm{~mm}$ ( $5 / 8$ de polegada) de diâmetro interno e empregando-se cola plās tica polimerizada (Araldite) para evitar a entrada de solução. Tambēm não foi obtido sucesso no experimento.

Um terceiro teste foi executado ligando-se os polos da pilha a cada lado do modelo condutor, intercalando-se uma resis tência em sērie no circuito para diminuir a corrente a um māximo de $1 \mathrm{~mA}$, impedindo assim que a pilha se descarregasse rapidamen te. A Figura 46 mostra os dados coletados. 0 modelo construído representa um polo negativo superficial.

A anāilise desta Figura estabelece que a curva deveria apresentar uma amplitude de variação muito maior que a obtida, considerando-se que o polo era superficial e sua diferença de po tencial era de $1500 \mathrm{mv}$, esta bem maior do que as encontradas na natureza.

0 resultado obtido talvez deva-se ao fato do modelo possuir resistividade nula, se comparada à da solução, contraste esse que favorece a passagem dos elëtrons pelo modelo, ao invëz dos mesmos deslocarem-se pela solução. 
Ficou evidente, porēm, que hă possibilidade de aplica ção deste mëtodo na construção de curvas-padrão para aplicação em casos reais, onde a anālise matemātica não tenha obtido sú cesso (ORELLANA, 1972). 
CAPITULO VI

\section{CONCLUSOES}

As informações obtidas com modelos reduzidos podem ser aplicadas a situações reais anālogas, devido ā proporcionalidade entre ambas. Essa proporcionalidade atribui à tēcnica de simulação experimental a função de preencher a lacuna constatada na anălise matemätica - que frequentemente não responde ques tões muitas vezes simples - como tambëm verificar a validade de conclusões teöricas.

A montagem do conjunto experimental, embora simples, requer cuidados especiais quanto a fatores que podem se comportar como origens de erros. Esses fatores, eliminados durante a construção e pela escolna dos equipamentos, possibilita a obten ção de um conjunto experimental com elevada precisão, embora a principal dificuldade esteja na escolna de materiais que possibilitem o contraste de resistividade desejado. 
CAP ITULO VII

\section{AGRADECIMENTOS}

0 A. cumpre com satisfação o dever de registrar a valiosa colaboração que recebeu de pessoas e entidades que, direta ou indiretamente, contribuiram para a elaboração deste traba 1 ho.

o Professor Doutor Andrē Davino, na posição de orientador, forneceu valioso aprendizado ao autor, com o qual foi possivel realizar esta dissertação.

Os Professores Dr. Osmar Sineli, Dr. Adonis de Souza e Alfio Bogdan, pertencentes ao Departamento de Geologia. Mine ralogia, Física e Matemātica da FFCL da USP no campus de Ribeirão Preto, muito colaboraram não somente com valiosas informações e incentivos quando o autor trabalhou no Laboratōrio de Geofísica Aplicada de Ribeirão Preto, como tambēm durante a mon tagem e funcionamento do Laboratōrio.de Rio Claro,fornecendo al guns aparelhos de medidas com os quais este trabalho foi concluỉdo. Agradecimentos tambēm devem ser feitos ao tëcnico em eletrōnica Hēlio de Almeida Prado, pelas valiosas sugestões dadas enquanto trabalhou no referido Departamento.

A Fundação de Amparo à Pesquisa do Estado de São Pau10 (FAPESP) forneceu verba para a compra dos equipamentos empregados no Laboratōrio de Ribeirão Preto.

Os geōlogos Victor Luiz de 01 iveira Meyer, responsävel pela Seção de Geofísica Aplicada, e Niza Silva Jardim, responsāvel pela Seção de Documentação, ambas seções pertencentes à Divisão de Geologia do Instituto de Pesquisas Tecnolōgicas $S$. A. (I.P.T.), muito colaboraram possibilitando emprēstimo de bibliografia indispensāvel à execução deste trabalho. 
0 Instituto de Geociēncias e Ciēncias Exatas,da UNESP, Campus de Rio Claro, forneceu preciosa verba para a aquisição e montagem da cuba eletrolitica e dos modelos reduzidos e o Departamento de Física desse Instituto emprestou equipamentos eletrồnicos importantes aos experimentos. Os docentes do Curso de Geologia do referido Instituto muito contribuiram incentivando o au tor em seu trabalho, enquanto ali desenvolveu atividades de docencia e pesquisa. Dentre eles destacaram-se os Professores Dr. Paulo Milton Barbosa Landim, Dr. Nivaldo J.Bōsio, Dr. Jorge $s$. Bettencourt, Dr. Eberhard Wernick, Dr. Paulo C. Soares e Alberto Pio Fiori.

O Professor Doutor Nelson Ellert forneceu valiosa orientação a este trabalho, quando da ausēncia do orientador em viagem ao exterior.

o geōlogo Yushiro Kihara, responsāvel pelo Laboratōrio de Mineralogia da Associação Brasileira de Cimento Portiand forneceu importante bibliografia e orientação nos assuntos relativos à resistividade de pasta de cimento.

A todos os que ajudaram, pessoas e entidades, mesmo àqueles involuntariamente não mencionados, o autor externa sua profunda gratidão. 
CAPITULO VIII

\section{BIBLIOGRAFIA}

AIKEN,C.L.; HASTINGS,D.A. \& STURGUL,J.R. - 1973 - Physical and computer modeling of induced polarization - Geophysical Prospecting, v.21, no4, pp.763-782

APPARAO,A.; ROY,A. \& MALLICK,K. - 1969 - Resistivity model expe riments - Geoexploration, v.7, nọ l, pp.45-54

ASSOCIAÇAO BRASILEIRA DE CIMENTO PORTLAND - 1969 - Concreto impermeävel - Bol. ne 71, 2a Ed., São Paulo, $6 \mathrm{p}$

ASSOCIAÇÃO BRASILEIRA DE CIMENTO PORTLAND - 1975 - Efeito de va rias substâncias sobre o concreto: Tratamentos proteto res - Bol. no 55, 2a Ed., São Paulo, 8 p

BASILIO,F.S. - 1972 - Durabilidade dos concretos: permeabilida de, corrosão eletrolitica - 2a Ed., ABCP, São Pau $10,48 \mathrm{p}$

BASILIO,F.S. - 1976 - Cimento portiand - $3 \stackrel{a}{\text { Ed., ABCP, São }}$ Pau10, $34 \mathrm{p}$

BOGDAN, A. - 1976 - Comunicacöes verbais

CAGNIARD,L. \& NEALE,R.N. - 1957 - Technique nouvelle de modëles rëduits pour la prospection ëlectrique - Geophysical Prospecting, v.5, ne 3, pp. 259-271

COGGON,J.H. - 1971 - Eletromagnetic and electrical modeling by the finite element method-Geophysics, v.36, nil,pp. $132-155$

COMPAGNIE GENERALE DE GEOPHYSIQUE - 1970 - Recueil de diagrammes electriques et trainés consécutifs relatifs $\bar{a}$ des structures complexes-mesures en baignoire

CONEY,D.P. - 1977 - Model studies of the VLF-EM method of geophysical prospecting - Geoexploration, v.15, n91, pp. $19-35$

DANIEL,I.M. \& MARINO,R.L. - 1971 - Wave propagation in a layered model due to point source loading in a high - impedance medium - Geophysics, v.36,nl3, pp.517-532 
DAVINO,A. - 1971 - Prospeção geofisica: conceituacão, mëtodos e campo de aplicąão - Mineração e Metalurgia, v.54, nọ 324 , p p $251-252$

DAVINO,A. - 1974 - Estudos sobre a prospeç̧ão magnetométrica das ocorrências de ferro na faixa Nova Era-Itamarandiba, Minas Gerais - Bol. Inst.Geoc., v.5, pp.1-16

ESTEVES,J.M. - 1966 - Contribuigão para a prospeção de estruturas geolögicas verticais por sondagens geoeléctricasTēcnica, v.28, nọ 356, pp.325-341, Lisboa, I.S.T.

EVJEN,H.M. - 1938 - Depth factors and resolving power of electri cal measurements - Geophysics, v.3, no2, pp.78-95

FITZPATRICK,G.L. - 1973 - Laboratory model studies in seismic ho Zography (abstr.) - $42^{\text {nd }}$ Annual International Meeting, Society of Exploration Geophysicists, Anahein, Califor nia

GAUR,V.K.; VERMA,0.P. \& GUPTA,C.P. - 1972 - Enhancement of elec tromagnetic anomalies by a conducting over burden Gepphysical Prospecting, v.20, no 3, pp.580-604

GAY Jr.,S.P. - 1963 - Standard curves for interpretation of magnetic anomalies over long tabular bodies Geophysics, v.28, nọ 2, pp. 161-200

GOUDSWAARD,W. - 1957 - On the effect of the tank wall material in geo-electrical model experiments - Geophysical Prospecting, v.5, no 3, pp.272-281

GUPTA SARMA,D. \& MARU,V.M. - 1971 - A study of some effects of a conducting host rock with a new modezzing apparatus Geophysics, v.36, no 1, pp.166-183

HEDSTROM,E.H. \& PARASNIS,D.S. - 1958 - Some model experiments re lating to eletromagnetic prospecting with special reference to airborne work - Geophysical Prospecting, v. $6, n \div 4, p p .322-341$

HEILAND,C.A. - 1968 - Geophysical exploration - 2a Ed., Hafner Publishing, New York, $1013 \mathrm{p}$

HILL,D.G. - 1972 - A Zaboratory investigation of electrical anisotropy in precambrian rock - Geophysics, v.37, no 6, pp. $1022-1038$ 
HOHMANN,G.H. - 1971 - Electromagnetic scattering by conductors in the earth near a line source of current - Geophysics, v. 36, ne1, pp.101-131

JAIN,S.C. - 1974 - Theoretical broadside resistivity profiles over an outcropping dyke - Geophysical Prospecting,v. 22, no $3, p p .445-457$

KELLER,G.V. \& FRISCHKNECHT,F.C. - 1966 - Electrical methods in geophysical prospecting - International Series of Mo nographs in Electromagnetic Waves, 10, Pergamon, New York, $517 \mathrm{p}$

KOEFOED,0.; VAN EWYK,J.G. \& BAKKER,W.T. - 1958 - Seismic model experiments concerning reflected refractions - Geophysical Prospecting, v.6, no 4, pp. 382-393

MUFTI,I.R. - 1976 - Finite-difference resistivity modeling for shaped two-dimensional structures - Geophysics,v. $41, n$ ? 1, pp. $62-78$

MUSKAi,M. \& EVINGER,H.H. - 1941 - Penetration in direct ourrent prospecting - Geophysics, V.6, ni4, pp.397-427

OGILVY,A.A.; AYED,M.A. \& BOGOSLOVSKY,V.A. - 1969 - Geophysical studies of water leakages from reservoirs - Geophysical Prospecting, v.17, nil, pp.36-62

ORELLANA,E. - 1972 - Prospecoion geoelectrica en corriente con tinua - Paraninfo, Madrid, $523 \mathrm{p}$

ORELLANA,E. - 1974 - Prospeccion geoelectrioa por campos varia bies - Paraninfo, Madrid, $571 \mathrm{p}$

PARASNIS,D.S. - 1973 - Mining geophysics (Methods in geochemis try and geophysics, 39) - Amsterdam, Elsevier, $356 \mathrm{p}$. (2르 Ed.)

ROY,A. \& APPARAO,A. - 1971 - Depth of investigation in direct current methods - Geophysics, v.36, ne5, pp.943-959

ROY,A. \& APPARAO,A. - 1976 - Laboratory results in resistivity logging - Geophysical Prospecting, v.24, ne1,pp.123140

RUST Jr.,W.M. - 1938 - A historical review of electrical prospecting methods - Geophysics, v.3,n?1, pp.1-6 
SATO,M. \& MOONEY,H.M. - 1960 - The electrochemical mechanism of sulfide self-potentials - Geophysics, v.25, n!l, pp. $226-249$

SCHLUMBERGER WELL SURVEYING CORPORATION - 1960 - Graficos para interpretacion de perfizes - Houston, Texas

SNYDER,D.D. - 1976 - A method for modeling the resistivity and induce polarization response of two-dimensional bodies - Geophysics, v.41, nọ5, pp.997-1015

SPIES,B.R. - 1976 - The derivation of absolute units in electro magnetic scale modeling - Geophysics, v.41, no5, pp. 1042-1047

SUMNER,J.S. - 1976 - Principles of induced polarization for geo physical exploration - Developments in Economic Geolo gy, n?5, Elsevier, New York, 277 p

UTZMANN,M.R. - 1954 - Prospection életrique et telZurique. Etudes sur modëles réduits - Bull. Assoc.Franç.Techn. Pétrole, no 107 , Paris, $61 \mathrm{p}$

VAN NOSTRAND,R.G. - 1953 - Limitations on resistivity methods as inferred from the buried sphere problem - Geophysics, v.18, n!2, pp.423-433. 